\title{
Histomorphological Studies on the Prostate Gland of Donkey Equus Asinus during Different Seasons
}

\author{
Alaa S. Abou-Elhamd, Ahmed O. Salem, and Aziza A. Selim \\ Department of Anatomy and Histology, Faculty of Veterinary Medicine, Assiut University, Assiut 71526, Egypt \\ Correspondence should be addressed to Alaa S. Abou-Elhamd; alaa88@yahoo.com
}

Received 19 May 2013; Revised 3 July 2013; Accepted 7 July 2013

Academic Editor: Francesco Cappello

Copyright ( 2013 Alaa S. Abou-Elhamd et al. This is an open access article distributed under the Creative Commons Attribution License, which permits unrestricted use, distribution, and reproduction in any medium, provided the original work is properly cited.

The objective of this study is to describe the histological and histochemical structures of the prostate gland during different seasons of the year. The experiment was carried out on the prostate gland of 24 sexually mature apparently healthy male donkeys (5 to 7 years) distributed over the four seasons of the year. The prostate gland was enveloped externally by a thick fibromuscular capsule. Fibromuscular septa arose from the deep aspect of the capsule dividing the prostate into variable numbers of lobules of different sizes and shapes. Each prostatic lobe was made up of compound tubuloalveolar glands and duct system. The secretory end pieces were lined with principal secretory cells with occasional few basal ones. The principal cells varied from columnar to cuboidal in shape, depending upon the studied season. The principal cells showed PAS-positive reactivity. Seasonal variations were observed in the height of the principal cell lining the secretory end pieces, in the interstitial tissue/glandular tissue ratio, and in the PAS reactivity in the principal cells. In conclusion, the prostate gland of donkey appeared more active during spring. This reactivity decreased during other seasons of the year. Minimal reactivity was recorded during winter.

\section{Introduction}

The accessory genital glands were a series of glands situated between the vas deferens and the root of the penis. These glands are responsible for the secretion of the seminal plasma, which provides the substrate for conveying the sperm to the female and ensuring final maturation $[1,2]$. The accessory genital glands of donkey were made up of ampulla ductus deferentis, seminal vesicles, prostate gland, bulbourethral glands, and urethral glands [3].

The secretory portions of the prostate were tubuloalveolar in rabbits [4], dogs [5], boars [6], elephants [7], bulls [8], equines [9], men [10], camels [11], and buffalo bulls [12]. In rams, the prostate was compound tubular [13], while in red deer and goats [14-16], it was of branched tubular type.

The epithelial lining of the secretory end pieces varied from low cuboidal to high columnar cells as observed in rabbits, boars, elephants, bulls, common marmoset, camels, buffalo bulls, domestic animals, and men ([4, 6-8, 17-21], resp.). In dogs, the lining epithelium was simple, stratified, or pseudostratified $[5,22]$. Frequently, flattened, large rounded, ovoid, wedged, or pyramidal-shaped cells were recorded between the lining cells of the secretory units of the prostate of dogs [22], shrew [23], camels [24], men [10], and buffalo bulls [17]. These basal cells possessed darkly stained cytoplasm and rounded nuclei with dense chromatin [18] in marmoset.

The glandular epithelium of the secretory end pieces of the prostate showed seasonal variations in red deer [14], bucks [15], rams [25], and camels [26].

The histological and histochemical studies on the prostate gland of equines especially those of donkeys are rare [9]. So the aim of the present work is to study the histological and histochemical structures of the prostate gland of donkey during different seasons of the year.

\section{Materials and Methods}

As discussed in our previous work [3], the present study was performed on 24 sexually mature apparently healthy male donkeys (jacks) that were collected during four seasons of the year, six for each. Their age ranged between 5 and 7 years. 


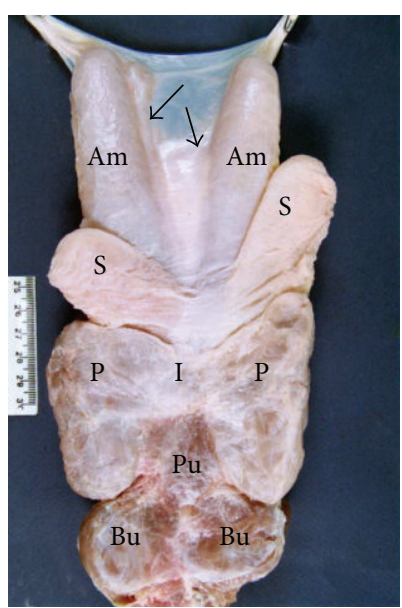

(a)

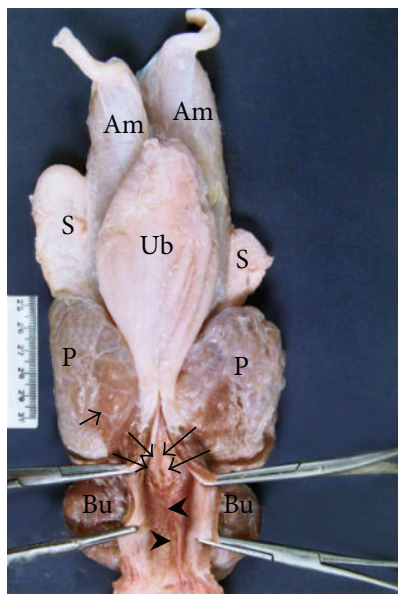

(c)

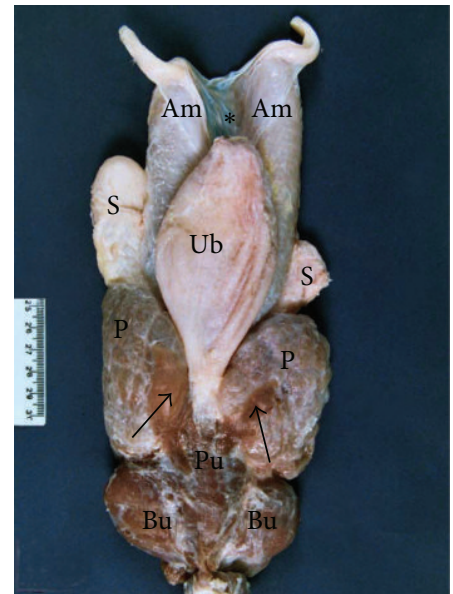

(b)

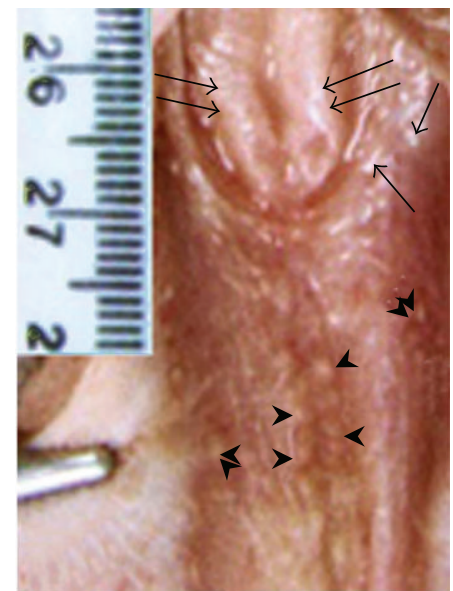

(d)

FIGURE 1: Photographs showing the accessory genital glands of the donkey during spring (dorsal view, (a); ventral view, (b)-(c)). Ductus deferens (arrowhead), ampulla of the deferent duct (Am), seminal vesicles (S), prostate gland (P) and its isthmus (I), band of urethralis muscle (arrow) covers the caudal pole of the prostate $(\mathrm{P})$, bulbourethral glands $(\mathrm{Bu})$, genital fold (asterisk), vestige Mullerian ducts (arrow), urinary bladder (Ub), and pelvic urethra $(\mathrm{Pu})$. (d) High magnification photograph at the ventral aspect of an incised pelvic urethra of the donkey during spring showing opening of the ejaculatory ducts (double arrows), prostate gland openings (arrows), bulbourethral gland openings (arrowhead), and urethral gland duct openings (double arrowheads) adapted after Abou-Elhamd et al., [3].

The animals were anesthetized and then thoroughly bled to death from the common carotid artery. The jacks were dissected, and their accessory genital glands were perfused in situ through the right and left internal pudendal arteries with the appreciate fixatives. They included neutral buffered formaldehyde, Bouin's fluid (for routine histological and morphometrical examination), and cold formol-calcium (for lipids).

The fixed specimens from the prostate gland were further processed for paraffin embedding. 5-7 $\mu \mathrm{m}$ thick paraffin sections were obtained and stained with the following stains. Routine histological examinations were performed by using Harris haematoxylin and eosin stain [27, 28]. Collagenous fibers were detected by Crossmon's trichrome stain $[29,30]$. For demonstration of elastic and reticular fibers, we used Verhoeff's methods [31, 32] and Gomori's reticulin stain [33], respectively. Periodic acid-schiff, PAS [34], alcian blue technique, $\mathrm{pH} 2.5$ [35], and combined alcian blue-PAS technique
[36] for detection of neutral and acid mucopolysaccharides. Glycogen was demonstrated by using Best's carmine method [37].

For demonstration of lipids, Sudan black staining as described by Bayliss and Adams [38]; we used the accessory genital glands of another 2 jacks each season.

The sections were examined and photographed on an Olympus microscope with DP72 camera and cell software.

For scanning electron microscopy, the specimens were fixed in 5\% phosphate buffered glutaraldehyde for $24 \mathrm{hr}$ at $4^{\circ} \mathrm{C}$. Thereafter, the specimens were post-fixed in $1 \%$ buffered osmic acid and dehydrated in alcohol followed by amyl acetate. They were dried by the critical point drying using liquid $\mathrm{CO}_{2}$ and mounted on specimen's tubes. The specimens were sputtercoated with gold, examined, and photographed at JEOL $5400 \mathrm{LV}$ scanning electron microscope.

The morphometric studies were performed on the stained histological sections of the glands under investigation using 


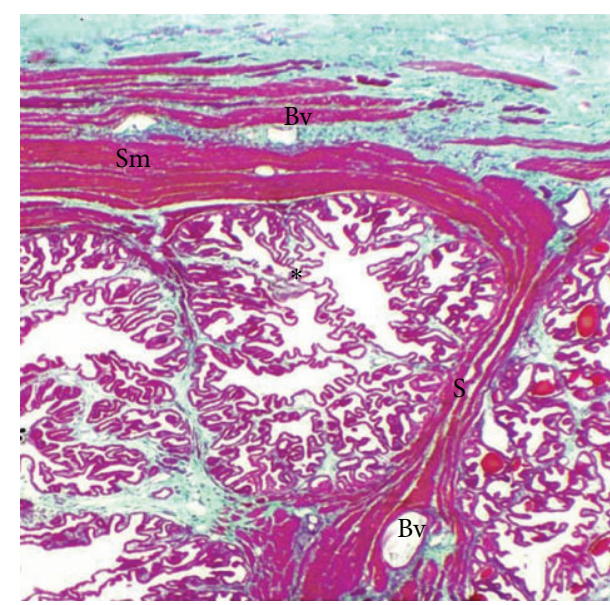

(a)

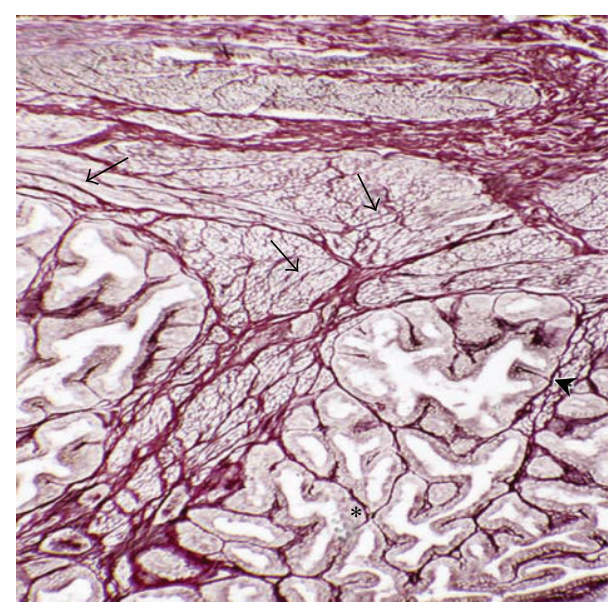

(b)

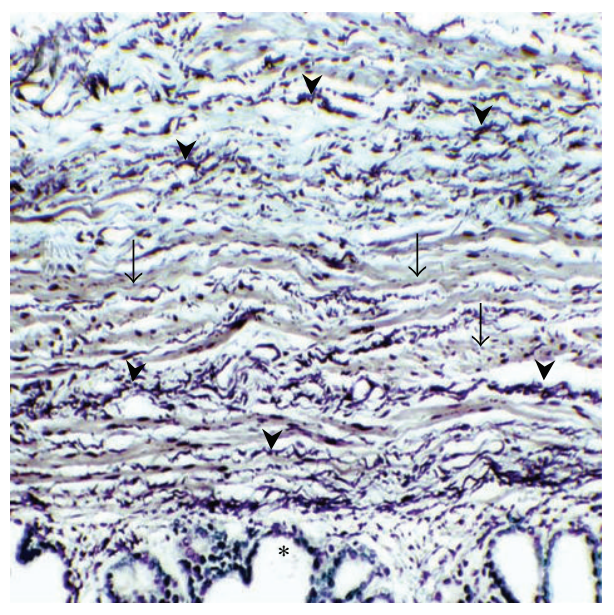

(c)

Figure 2: Photomicrographs of the fibromuscular capsule of the prostate of the donkey during winter by using of (a) Crossmon's trichrome stain showing the smooth muscle fiber bundles $(\mathrm{Sm})$ and collagen fibers (green colour). Septa (S), prostatic lobules (asterisk), blood vessels (Bv), and $\times 25$. (b): Verhoff's stain showing the elastic (arrowhead) and smooth muscle fibers (arrow). Secretory end pieces (asterisk), $\times 200$. (c): Gomori's stain showing the reticular fibers network (arrowhead) supporting the smooth muscle fibers. Collagen fibers (brown colour), prostatic lobules (asterisk), and $\times 100$.

Leica Q 500 MC image analyser. They were performed by two operators, in double blind, comparing the results obtained subsequently. The measurements were carried out on each gland of the 6 jacks in all seasons in the following manner. The height of the surface and the glandular epithelium, the nuclear/cell ratio of the principal cells of the surface, and glandular epithelium were calculated from fifteen random fields of the glands under investigation. The interstitial connective tissue/glandular tissue ratio of the studied glands was calculated from five random fields. All the data were presented as means \pm SE, which were statistically analysed using SPSS (one way ANOVA and Scheffe tests).

\section{Results}

The prostate gland (Glandula prostatica) of the donkey was represented only by the body or the external part of the gland (Pars externa, Corpus prostatica), which was retroperitoneal.
It consisted of right and left somewhat prismatic-shaped lobes connected with isthmus. The prostate gland was located on the dorsolateral surface of the neck of the urinary bladder and the beginning of the urethra. Caudally, a muscular band originating from the urethralis muscle covered partially each prostatic lobe at its ventral surface. After incision of the ventral aspect of the pelvic urethra, 15-20 duct openings of the prostate were observed on both sides of the Colliculus seminalis (Figures $1(\mathrm{a})-1(\mathrm{~d})$ ).

3.1. Histological Observations. The prostate gland of the donkey consisted of stroma and parenchyma. The former was represented by capsule, septa, and interstitial connective tissue.

The prostate gland was enveloped externally by a thick capsule. The capsule was divided into outer fibrous and inner fibromuscular layers. The outer fibrous capsule was made up mainly of collagenous, reticular, and few fine elastic fibers 


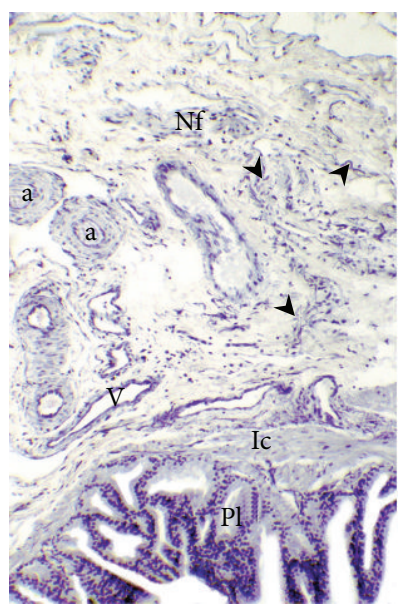

(a)

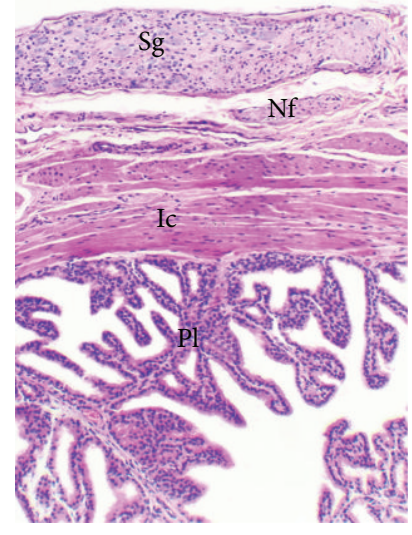

(b)

FIGURE 3: Photomicrographs of the prostatic capsule during winter showing fine elastic fibers (arrowhead), small-sized arteries (a), smallsized veins $(\mathrm{V})$, bundles of myelinated nerve fibers $(\mathrm{Nf})$, and sympathetic ganglion $(\mathrm{Sg})$ within the outer fibrous layer. Inner fibromuscular capsule (Ic), and prostatic lobules (Pl). (a) Verhoff's stain. $\times 50$. (b) Haematoxylin and eosin $\times 100$.

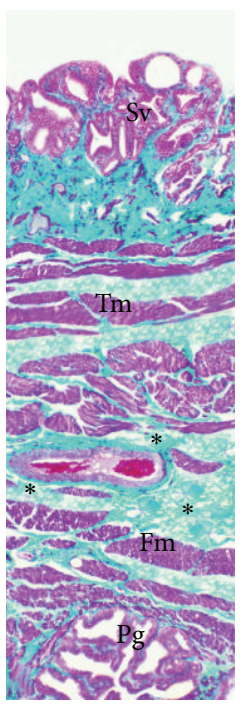

FIGURE 4: Photomicrograph showing the attachment (asterisk) of the seminal vesicle (Sv) with the capsule of the prostate gland $(\mathrm{Pg})$ during winter. Collagen fibers (green colour). Tunica muscularis of the seminal vesicle $(\mathrm{Tm})$, and fibromuscular capsule of the prostate (Fm). Crossmon's trichrome stain. $\times 100$.

(Figures 2(a)-2(c)). This layer contained small-sized arteries and veins, arterioles, venules, bundles of myelinated nerve fibers, and sympathetic ganglia (Figures 3(a) and 3(b)).

The inner fibromuscular capsule consisted mainly of coarse collagenous fibers and thick bundles of smooth muscle ones (Figure 2(a)). The latter were concentrated mainly in the deep portion of the capsule with abundant elastic fibers. Moreover, fine elastic ones were seen elsewhere in the capsule in between the individual smooth muscle fibers (Figure 2(c)).

It was observed that the prostatic capsule is attached directly to the connective tissue adventitia of the seminal vesicle cranially at its dorsal aspect (Figure 4). In addition, bundles of skeletal muscle fibers of the urethralis muscle were also demonstrated, joining the prostatic capsule at its caudal pole ventrally (Figure 5(a)). Some of these skeletal muscle fibers penetrated the capsule and were demonstrated among the smooth muscle fiber bundles of the septa only in sections obtained from the caudal pole of the prostate (Figure 5(b)).

Fibromuscular septa arose from the deep aspect of the capsule (Figures 2(a) and 2(b)) dividing the prostate into variable numbers of lobules of different sizes and shapes (Figure 6(a)). Structurally, the septa simulated nearly the capsule (Figure 6(b)), but the elastic fibers appeared more numerous and thicker (Figure 6(c)). It also contained smallsized blood vessels and bundles of myelinated nerve fibers.

The interstitial tissue of the prostate was made up mainly of a network of reticular fibers supporting the glandular end pieces (Figure 7(a)). In addition to the presence of fine elastic (Figure 7(b)) and collagenous fibers, singly distributed smooth muscle fibers were also demonstrated (Figures 8(a) and $8(\mathrm{~d}))$.

The amount of the interstitial connective tissue supporting the prostatic parenchyma varied among the studied seasons, where highly significant $(P<0.01)$ seasonal differences in the interstitial connective tissue/glandular tissue ratio were recorded. The lowest amount of the interstitial tissue was obtained in spring, where the interstitial connective tissue/glandular tissue ratio reached about $0.247 \pm 0.015$. This ratio increased gradually during summer (about $0.295 \pm$ 0.019 ) and autumn (about $0.400 \pm 0.025$ ), while the highest ratio was observed during winter, where it measured about $0.480 \pm 0.018$ (Figures 8(a)-8(d) and Figure 9).

The parenchyma of the prostatic lobes and isthmus is composed of compound tubuloalveolar glands and duct system (Figures 2(a), 5(a) and 8(a)-8(d)).

The compound tubuloalveolar glands were lined with principal secretory cells with, however, occasional few basal 


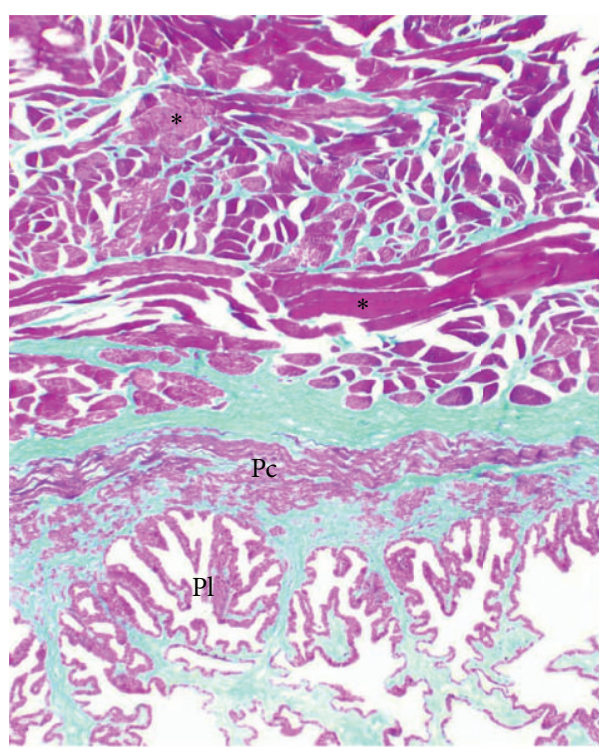

(a)

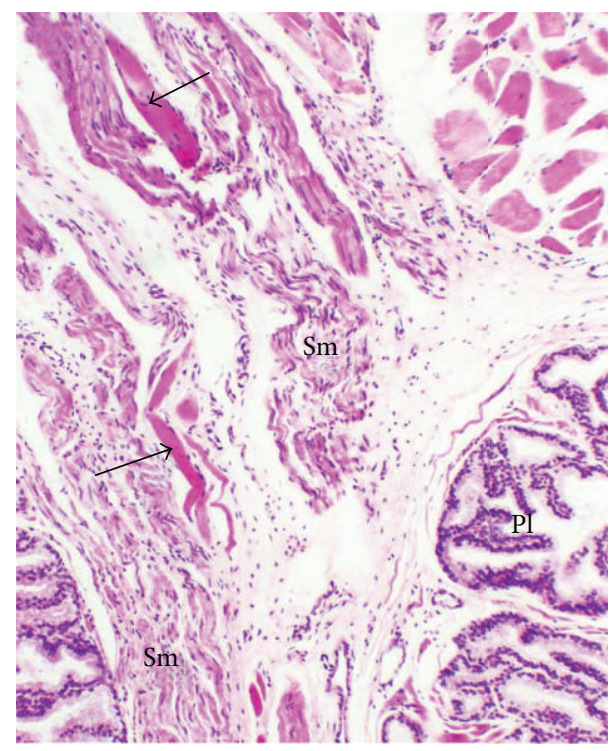

(b)

FIGURE 5: Photomicrographs showing the site of attachment of the skeletal muscle fibers (a) of the urethralis muscle (asterisk) to the prostatic capsule (Pc) and the extension of some these fibers (arrow) within the fibromuscular septa (b). Collagen fibers (green colour), smooth muscle fibers $(\mathrm{Sm})$, and prostatic lobules $(\mathrm{Pl})$. (a) Crossmon's trichrome stain. $\times 50$. (b) Haematoxylin and eosin stain. $\times 100$. (asterisk).

ones. The principal cells varied from columnar to cuboidal in shape, depending upon the studied season with somewhat distinct cell boundaries and fine granular acidophilic cytoplasm, which appeared more numerous during spring than the other seasons. Their deeply stained basely located nuclei were nearly round or ovoid in shape. Also, fine dark yellow to yellow brown granules were distributed within the cytoplasm of the glandular and ductal epithelial cells of the prostatic lobules. Large amount of these granules was clearly visible during winter. The basal cells appeared as small flat or triangular-shaped cells, wedged between the principal ones and the basement membrane. They were characterized by their somewhat small cytoplasm and large flattened or irregular-shaped nuclei (Figures 10(a)-10(b)).

The height of the glandular epithelium revealed highly significant $(P<0.01)$ seasonal variations. During spring, the epithelial height reached its maximal value, where it measured about $14.67 \mu \mathrm{m} \pm 0.138$. Then, it decreased gradually during summer (about $12.80 \mu \mathrm{m} \pm 0.397$ ) and autumn (about $12.64 \mu \mathrm{m} \pm 0.279$ ). The lowest value was obtained in winter, where it was about $11.31 \mu \mathrm{m} \pm 0.322$ (Figures 11 and $12(\mathrm{a}$ )$12(d))$.

The nuclear/cell ratio of the principal cells of the prostate varied among the studied seasons. This ratio showed highly significant $(P<0.01)$ seasonal variations. The lowest ratio was recorded in spring, where it reached about $0.224 \pm 0.013$. This ratio increased gradually to about $0.225 \pm 0.005$ during summer, $0.241 \pm 0.005$ during autumn, and $0.270 \pm 0.009$ during winter (Figure 9).

The lumina of some secretory portions as well as that of the central collecting sinuses showed acidophilic secretory materials as well as concretes.
The duct system could be organized into tertiary, secondary, and primary ducts. The secretory portions were drained directly by a tertiary duct into a secondary duct or the central collecting sinus of the prostatic lobules (Figure 13(a)). The glandular epithelium of the secretory portions changed gradually into the ductal epithelium. Both the tertiary and secondary ducts and central collecting sinuses were lined with low cuboidal principal cells, with somewhat deeply stained acidophilic cytoplasm. Their spherical or ovoid nuclei appeared somewhat darkly stained occupying most of the cell (Figure 13(b)).

The secondary ducts or central collecting sinuses of several prostatic lobules or even of a single lobule are drained directly into a long primary duct (Figure 14). These primary ducts were accompanied with few secretory end pieces, which opened directly into their lumina. The ducts were directed towards the cranial part of the pelvic urethra penetrating its muscle (Figures 15(a) and 15(b)) to open on both sides of the Colliculus seminalis. These ducts were firstly lined with simple low cuboidal epithelial cells as those of the central collecting sinus, which changed gradually into a bilayered epithelium, consisting of superficial cuboidal cells and flat basal ones. Near its termination, the ductal lining epithelium changed into stratified cuboidal at its opening into the pelvic urethra (Figure 16(b)).

The primary ducts were supported with highly vascular dense fibrous connective tissue layer made up mainly of collagenous (Figure 16(a)). Reticular fibers network was observed only under the epithelial lining of the duct and secretory portions (Figure 15(b)). Elastic fibers were demonstrated mainly parallel to the longitudinal axis of the duct (Figures 17(a) and 17(b)). This connective tissue layer contained also fibroblasts, fibrocytes, and blood vessels of 


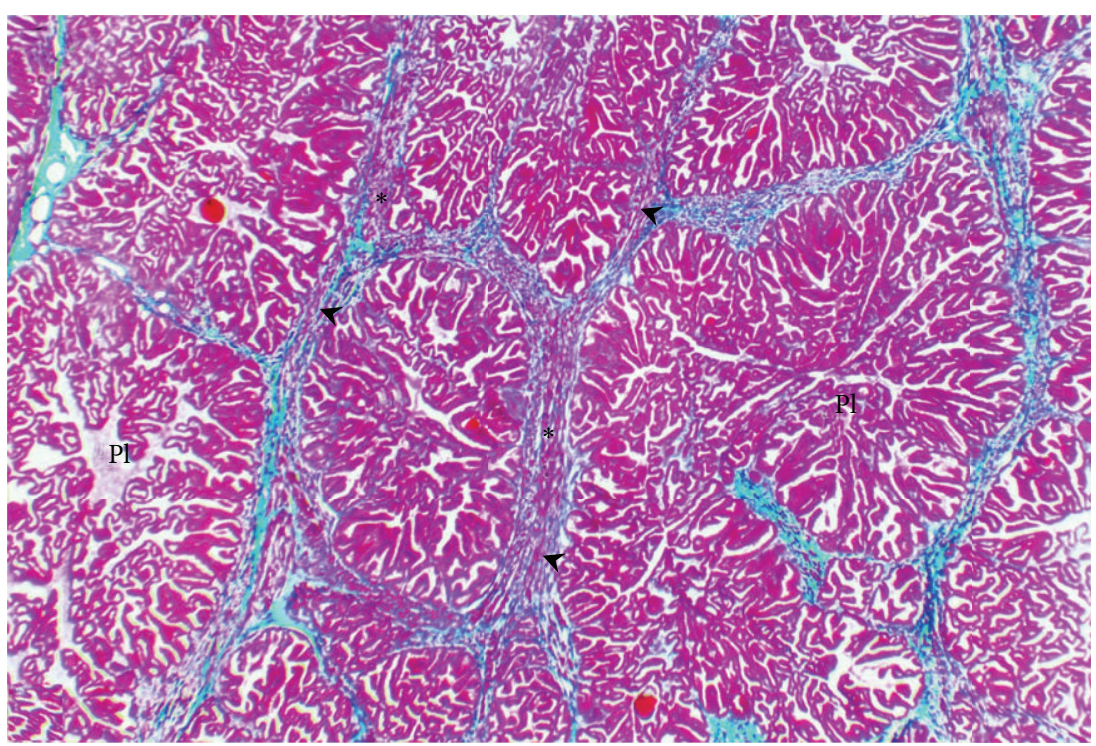

(a)

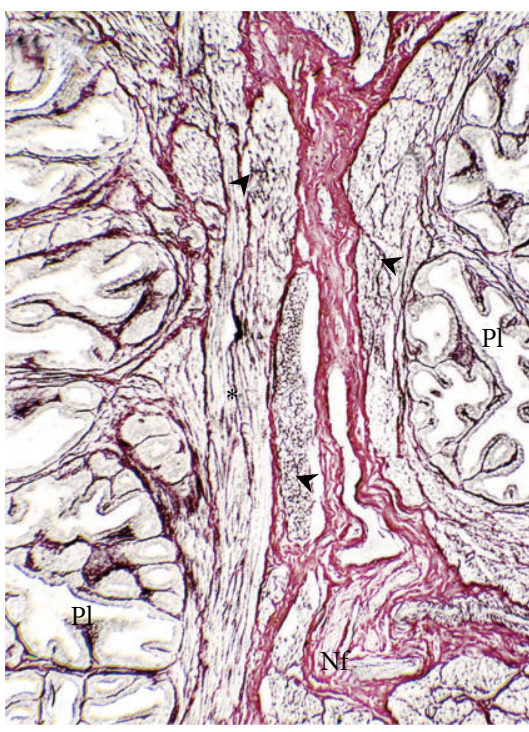

(b)

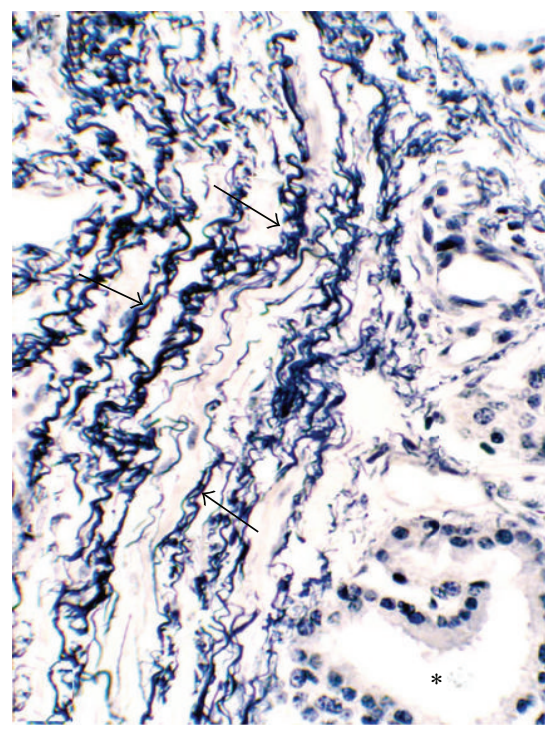

(c)

Figure 6: Photomicrographs of the fibromuscular capsule of the prostate of the donkey during winter after by using of (a) Crossmon's trichrome stain showing the smooth muscle fiber bundles (Sm) and collagen fibers (green colour). Septa (S), prostatic lobules (asterisk), and blood vessels $(\mathrm{Bv}) . \times 25$. (b) Gomori's stain showing the reticular fibers network (arrowhead) supporting the smooth muscle fibers. Collagen fibers (brown colour), and prostatic lobules (asterisk). $\times 100$. (c) Verhoff's stain showing the elastic (arrowhead) and smooth muscle fibers (arrow). Secretory end pieces (asterisk). ×200.

variable calibers as well as cavernous spaces (Figures 15(a), 15(b), and 16(a)).

Scanning electron microscopy of the pelvic urethra during the studied seasons at the level of the Colliculus seminalis revealed numerous prostatic duct openings (Figure 18(a)), which are arranged into somewhat parallel rows on either side of the Colliculus seminalis. These openings appeared as elevated dome-shaped papillae upon the urethral membrane. At the tip of each papilla, the prostatic gland openings possessed irregular indentations and hexagonal-shaped cell luminal surface (Figures 18(b) and 18(c)). Variable numbers of spermatozoa could be observed within some prostatic duct openings (Figure 18(d)).

\subsection{Histochemical Observations}

\subsubsection{Carbohydrates}

Neutral Mucopolysaccharides. During spring, the principal glandular epithelial cells lining the majority of the secretory end pieces of the prostatic lobules reacted very strongly to PAS in the form of diffuse homogenous substance filling the 


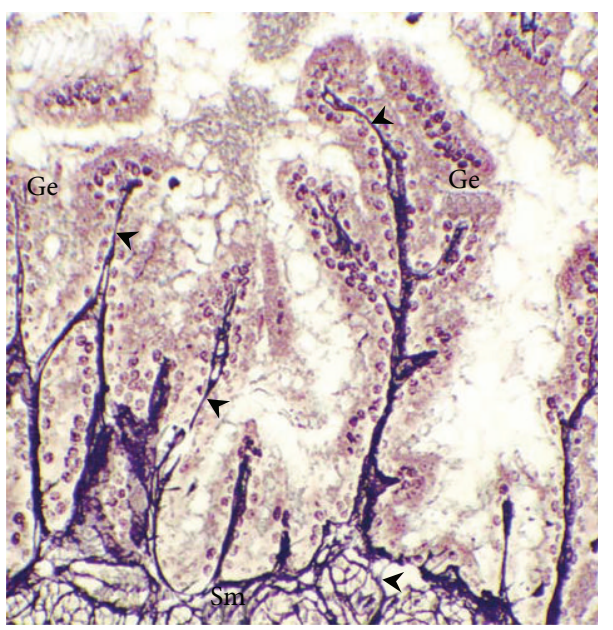

(a)

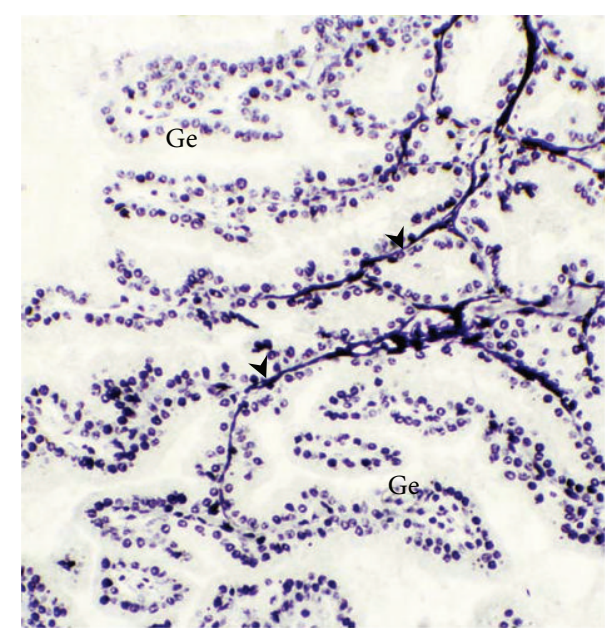

(b)

Figure 7: (a) Photomicrographs showing the reticular fibers network (arrowhead) supporting the muscle fibers of the septa (asterisk) during winter. Collagen fibers (brown colour), myelinated nerve fiber bundles (Nf), and prostatic lobules (Pl). Gomori's stain. $\times 100$. (b) Photomicrograph showing the numerous elastic fibers (arrow) within the septa of the prostate of the donkey during winter. Secretory end pieces (asterisk). Verhoff's stain. $\times 400$. (a)-(b), (a) Photomicrograph of the prostatic lobules during spring showing reticular fibers network (arrowhead) supporting the glandular epithelium $(\mathrm{Ge})$ and smooth muscle fibers of the septa $(\mathrm{Sm})$. Gomori’s stain. $\times 200$. (b) Photomicrograph showing fine elastic fibers (arrowhead) in the interstitial connective tissue of the prostate of the donkey during spring. Glandular epithelium (Ge). Verhoff's stain. $\times 200$.

whole cytoplasm (Figure 19(a)). It was observed that in some glandular lobules or even in the same secretory portions, the intensity of the PAS-positive reactivity ranged from strong to moderate. But secretory portions that negatively reacted to PAS could not be demonstrated. The secretory materials observed within the lumina of some prostatic lobules showed very strong positive reaction. The epithelial lining of the duct had the same reactivity as that of the glandular one.

During summer, the intensity of the PAS reaction was somewhat slightly lower than that during spring (Figure 19(b)). During autumn, a moderate PAS-positive reactivity was observed within the majority of the prostatic lobules, although some of them weakly reacted (Figure 19(c)), while the secretory globules very strongly reacted. During winter, the majority of the secretory portions of the prostatic lobules weakly reacted to PAS, although few secretory portions showed moderate PAS reactivity. On the other hand, strong PAS-positive granules were detected within some glandular and ductal epithelial cells (Figure 19(d)).

In all studied seasons, the prostatic stroma weakly reacted to PAS while the reticular fibers supporting the smooth muscle fibers strongly reacted (Figures 19(a)-19(d)).

3.3. Glycogen. After Best's carmine staining, the prostate gland of the donkey did not reveal any positive glycogenic granules during the four seasons. Only the luminal content showed somewhat moderate reaction for Best's carmine stain (data not shown).

3.4. Acid Mucopolysaccharides. During the four studied seasons, the glandular and ductal epithelium of the prostatic lobules as well as the luminal contents, concretes, the capsule, septa, and the interstitial connective tissue were devoid of any alcianophilic positive reaction (Figures 20(a) and 20(b)).

With alcian blue-PAS staining technique, the histochemical picture of the prostate gland of the donkey concerning the pattern of distribution and the intensity of reaction was nearly the same as that observed with PAS technique during the all studied seasons (Figures 21(a) and 21(b)).

3.5. Lipids. During spring, few sudanophilic granules were observed within the glandular and ductal epithelial cells of the prostate gland of the donkey. They were represented by small granules within the majority of these cells (Figure 22(a)). During the other seasons, the intensity and amount of sudanophilic granules increased than those observed during spring (Figure 22(b)). The components of the capsule, connective tissue septa and the secretory substances negatively reacted to Sudan black stain.

3.6. Lipofuscins. After long Ziehl-Neelsen staining, few positive lipofuscin granules could be demonstrated during spring in some glandular and ductal epithelial cells of the prostatic lobules. These granules were nearly rounded ranging from bright red to magenta colour (Figure 23(a)). They increased slightly during summer (Figure 23(b)) while during autumn a further increment in their amount could be observed (Figure 23(c)). These lipofuscin pigments reached their maximal amount during winter (Figure 23(d)). In all studied seasons, lipofuscin pigments within the stroma of the prostatic glands of the donkey and the luminal contents could not be demonstrated. 


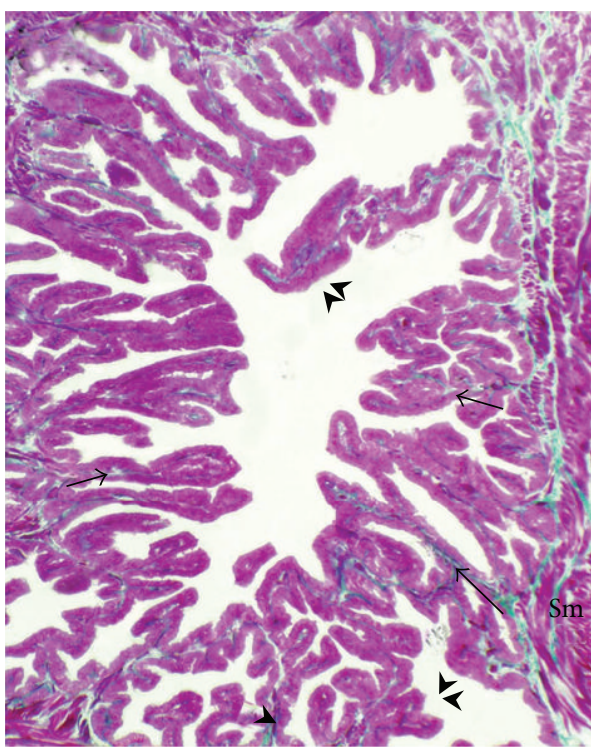

(a)

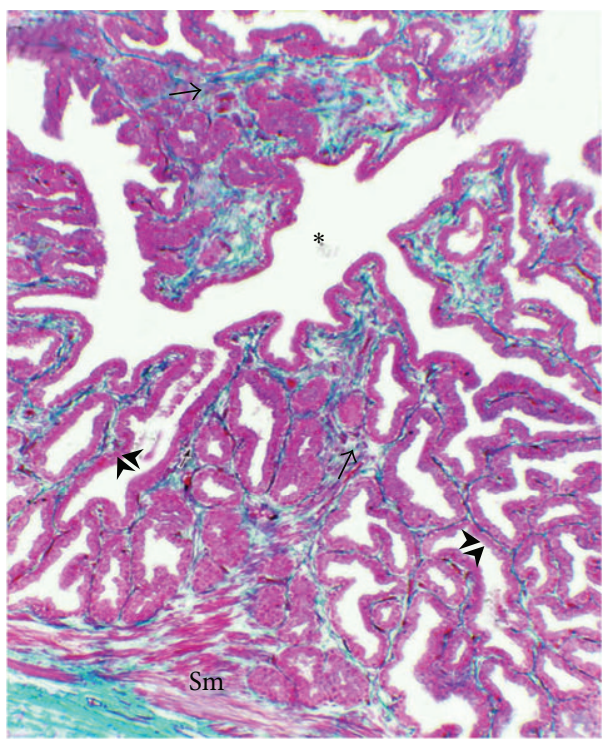

(c)

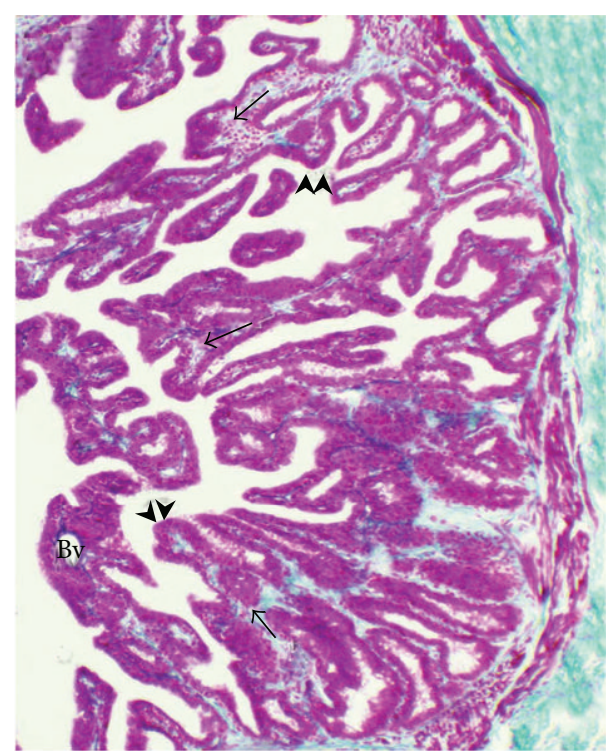

(b)

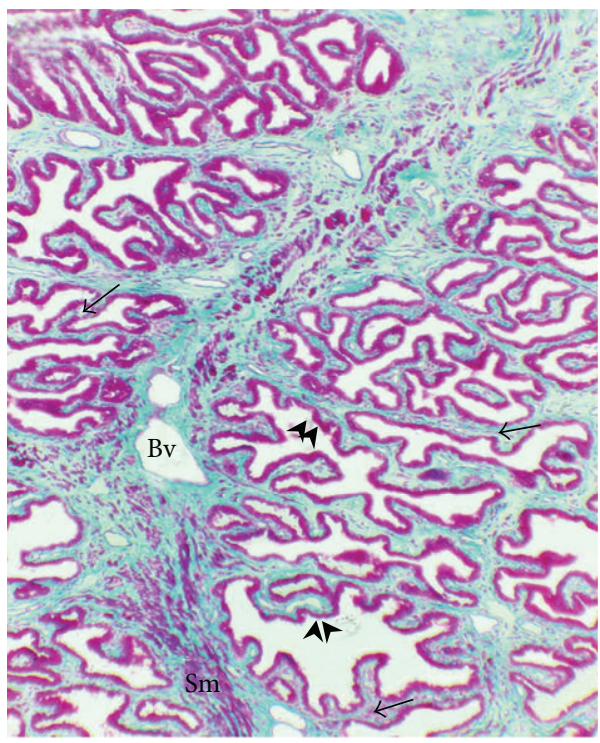

(d)

FIGURE 8: Photomicrographs showing the variation in the amount of the interstitial connective tissue (arrow) of the prostate gland of the donkey during spring (a), summer (b), autumn (c), and winter (d). Glandular epithelium (double arrowhead), collagen fibers (green colour), smooth muscle fiber bundles of the septa $(\mathrm{Sm})$, singly distributed smooth muscle fibers (arrowhead), central collecting sinus (asterisk), and blood vessels $(\mathrm{Bv})$. Crossmon's trichrome stain. $\times 100$.

\section{Discussion}

The prostate gland of the donkey was made up only of Pars externa (Corpus prostatae), which consisted of right and left lobes, connected with isthmus and located on the dorsolateral surface of the neck of the urinary bladder and the beginning of the urethra. Similar results were reported in horses $[19,39-$ 41] and equines [2,9].

The prostate of the donkey was enveloped by thick capsule which had outer fibrous and inner fibromuscular layers. Simulated results were reported in bulls $[8,42,43]$, common marmoset [18], horses [40], camels [11], and buffalo bulls [44].
The present study revealed that the capsule of the prostate is attached directly to the connective tissue adventitia of the seminal vesicles. This may be the cause of the difficulty to distinguish them on rectal palpation in horses [40].

The connective tissue septa of the prostate of the donkey were mainly fibromuscular in nature. Similar results were observed in bulls $[8,43]$ and buffalo bulls $[17,42,45]$, while in camels, it was less fibrous and more muscular [11, 26, 46, 47].

The present study revealed that the interstitial tissue of the prostate gland of the donkey was made up of a network of reticular fibers supporting the glandular end pieces as that observed in the prostate of camels and buffalo bulls $[26,48]$. 


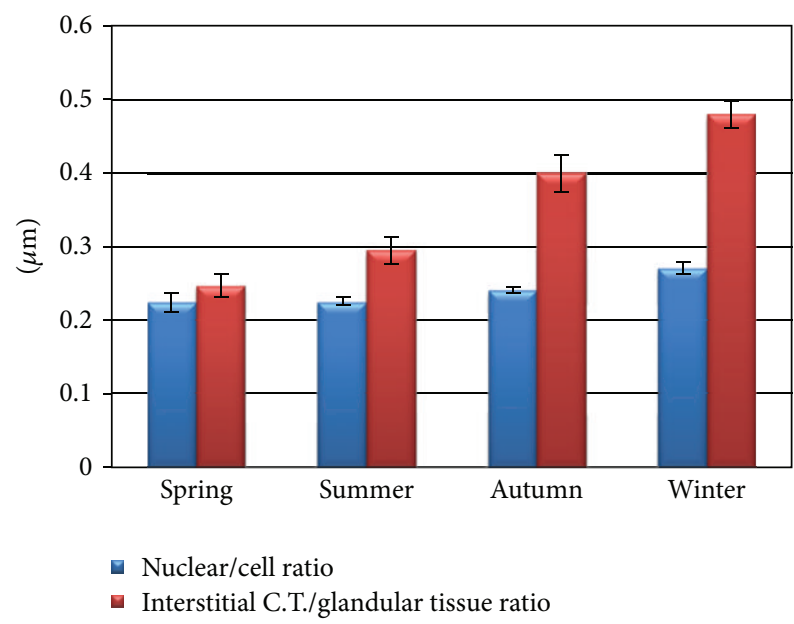

FIGURE 9: The nuclear/cell ratio of the principal cells of the glandular epithelium and the interstitial connective tissue/glandular tissue ratio of the prostate gland of the donkey showed significant seasonal variations.

In addition, fine elastic and collagenous fibers as well as single distributed smooth muscle fibers were also observed. A great amount of smooth muscle fibers were demonstrated in the interstitial connective tissue of the prostate gland of camels [46], stallions [19], and Mongolian gerbil [49]. The contraction of this muscle may be required to push the stored prostatic secretion into the lumen of the urethra $[11,50]$.

The parenchyma of the prostate gland of donkey was compound tubuloalveolar in type. However, it was of compound tubular type in red deer, horses, bucks, and domestic animals ([14, 15, 39, 40], resp.).

The present study revealed that the glandular epithelium of the prostate is made up of principal secretory cells with occasionally few basal ones. Similar description was observed in dogs [5], goats [51], common marmoset [18], camels [20, 46], goats [52] and domestic animals [19], while the glandular epithelium of the prostate of bucks [15], buffalo bulls [12, 48], gorilla [53], and camel [11] ranged from cuboidal to columnar.

The present study revealed that the principal glandular cells were columnar in shape with fine granular acidophilic cytoplasm. The basal cells appeared as small flat or triangularshaped.

These cells were considered as a source of cellular regeneration and played a role in substrate transport [54]. This was supported by Chandler et al. [55] as after administration of cadmium to rats, the basal cells were found to replace epithelial cells in vivo.

Contrary to that observed in male opossum [56] and camels $[11,20,26]$, the apical surface of the principal cells of the prostate of the donkey showed no apical protrusions, and this suggests that the mode of secretion of these cells may be a merocrine type. This finding was in agreement with that observed in dogs [57] as well as in bucks [58]. Both merocrine and apocrine modes of secretion were observed in the prostate gland of Mongolian gerbil [49].

Similar to that observed in the glandular epithelium of the prostate gland of baboons [59], dogs [60, 61], and house

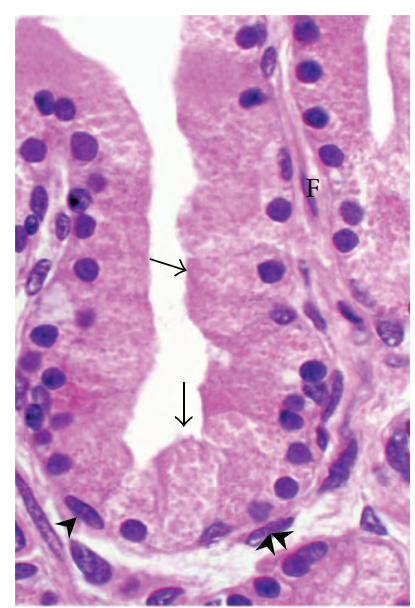

(a)

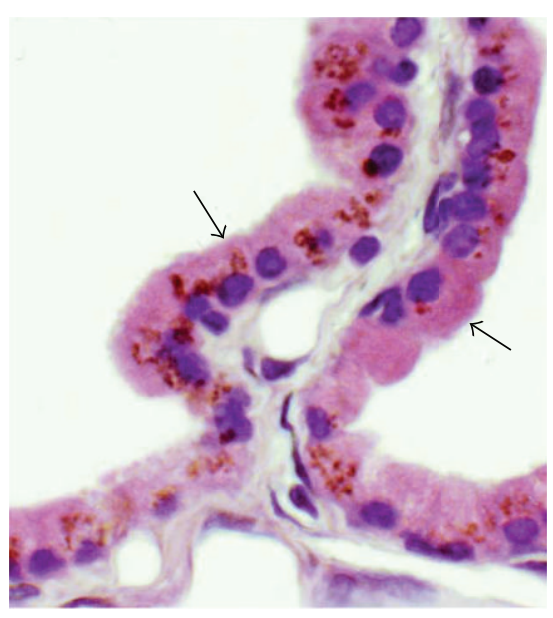

(b)

FIgURE 10: Photomicrographs of the glandular epithelium of the prostate during spring (a) and winter (b) showing the principal cells with fine acidophilic granular cytoplasm and rounded basely located nuclei (arrow). During winter, the principal cells contained large amount of lipofuscin pigments (brown colour). Basal cells with flattened (arrowhead) or irregular-shaped nuclei (double arrowhead), Fibroblasts (F). Haematoxylin and eosin stain. $\times 1000$.

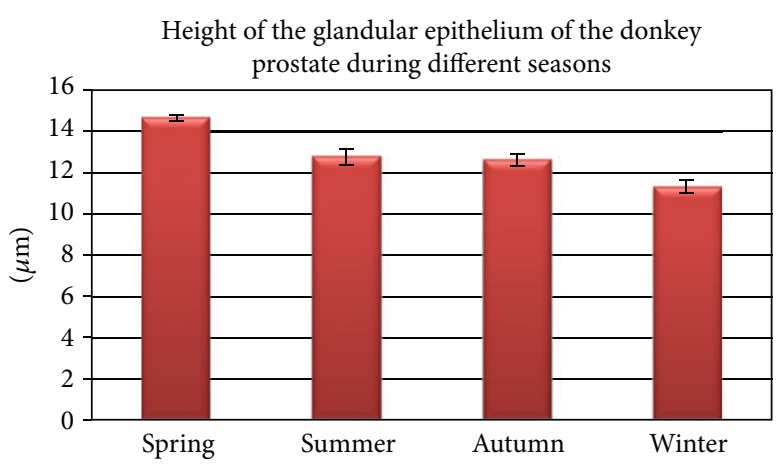

FIGURE 11: The height of the glandular epithelium of prostate gland of the donkey showed significant seasonal variations. 


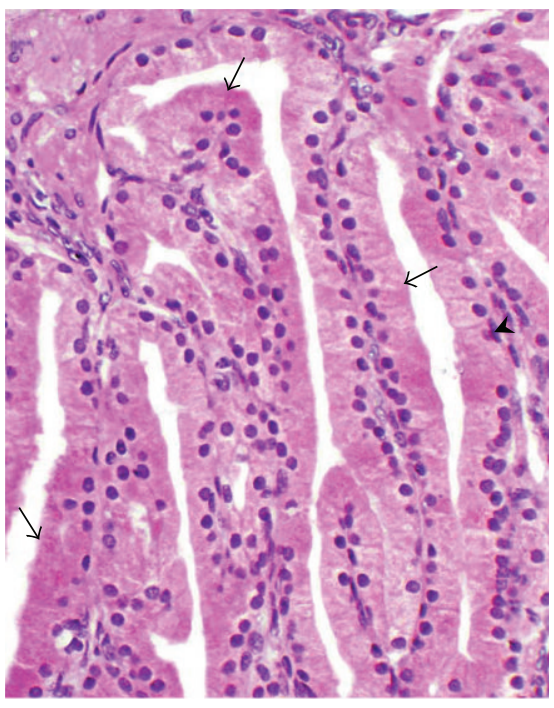

(a)

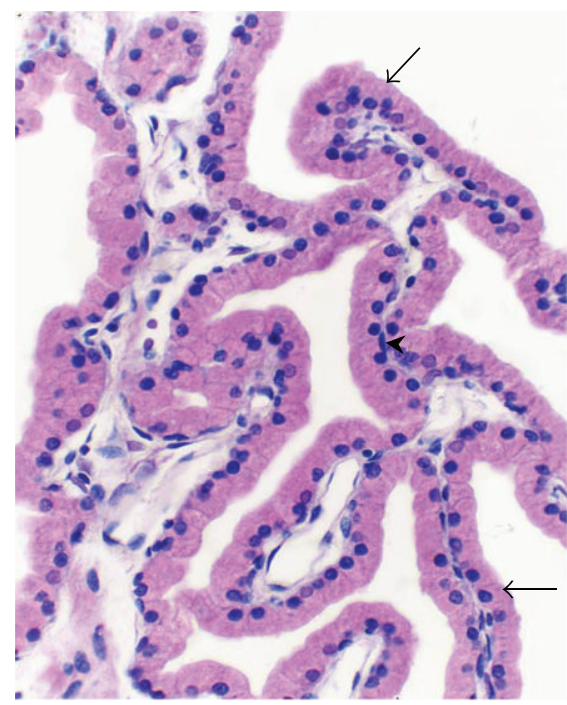

(c)

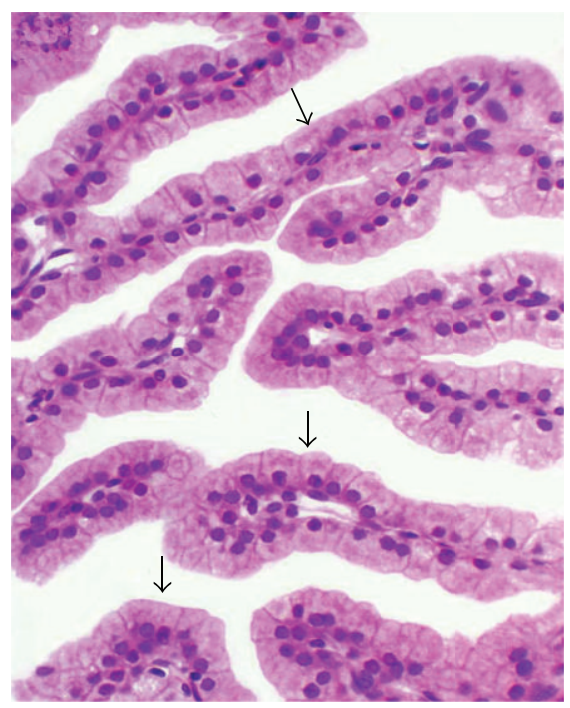

(b)

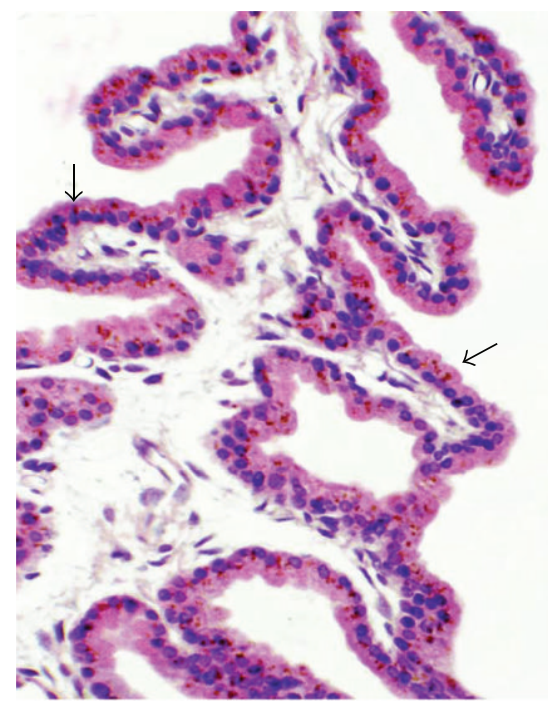

(d)

FIGURE 12: Photomicrographs showing the variation in the height of the glandular epithelium of the prostate during spring (a), summer (b), autumn (c), and winter (d). Principal cells (arrow), basal cells (arrowhead), and lipofuscin granules (brown colour in (d), fibroblasts (F). Haematoxylin and eosin stain. $\times 400$.

mice [62], fine dark yellow to yellow brown granules were distributed within the cytoplasm of the glandular and ductal epithelium of the prostate of the donkey. These granules were histochemically similar to lipofuscin pigments [21]. The prostatic stromal and glandular cells of the prostate gland of dogs underwent serial pathological changes of atrophy and apoptosis after castration. The atrophic cells were filled with numerous intracellular lipofuscin pigments. This indicates that the prostate was an androgen sensitive organ. Reference [62] added that there was an increase in apoptotic cells in ventral prostate of house mice on ageing related to the fall of testosterone level and increase of lipofuscin granules, which may be indicative stress in this tissue. In men prostatic tissue, the increase of lipofuscin might be secondary to cellular damage with a consequent catabolic process in the cells [63]. This confirmed the present results, in which lipofuscin pigments were observed during winter (in active season) and decreased during the rest of the seasons, where they reached their minimal amount during spring (active season).

The prostate gland of donkey reached its maximal activity during spring, where the glandular epithelium reached its maximal height (about $14.67 \mu \mathrm{m} \pm 0.138$ ), and the nuclear/cell ratio of the principal cells reached the lowest value (about $0.224 \pm 0.013)$. The connective tissue was sparse, where the interstitial connective tissue/glandular tissue ratio reached the lowest value (about $0.247 \pm 0.015$ ). The lowest activity was observed during winter, where the cell height reached the lowest value (about $11.31 \mu \mathrm{m} \pm 0.322$ ), and the nuclear/cell 


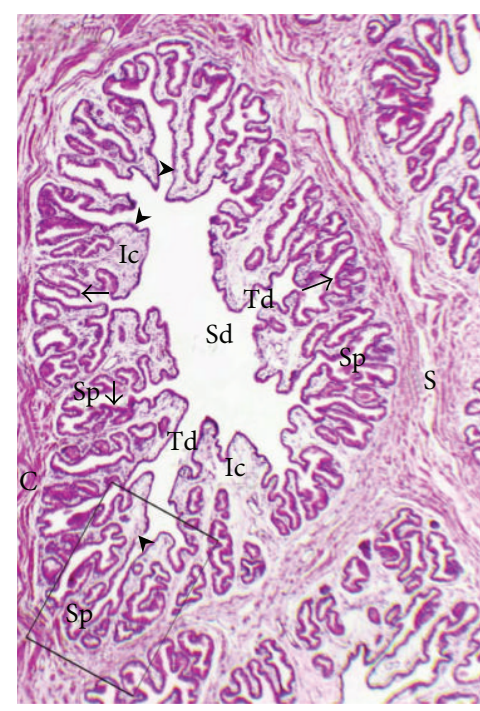

(a)

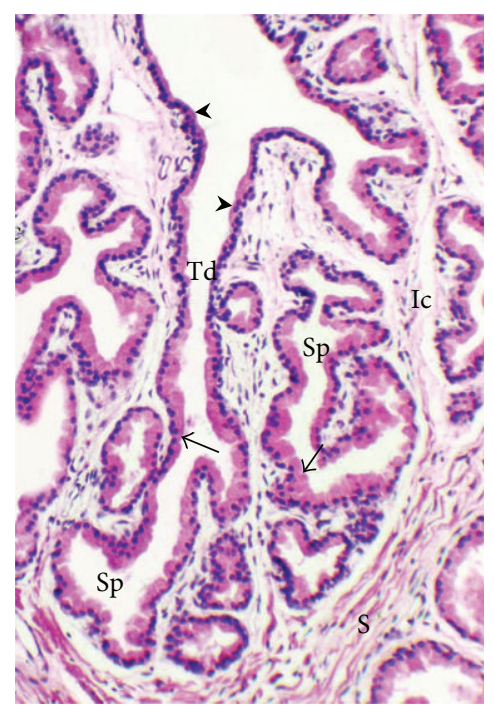

(b)

FIGURE 13: Photomicrographs of the prostatic lobules (a) and the higher magnification of the marked area (b) during winter. The secretory portions (Sp) drained by a tertiary duct (Td) into large secondary duct or collecting sinus (Sd), gradual change of the glandular epithelium (arrow) into ductal one (arrowhead). Fibromuscular capsule (C) connective tissue septa (S), interstitial connective tissue (Ic). Haematoxylin and eosin stain. $(\mathrm{a}): \times 50$. (b): $\times 200$.

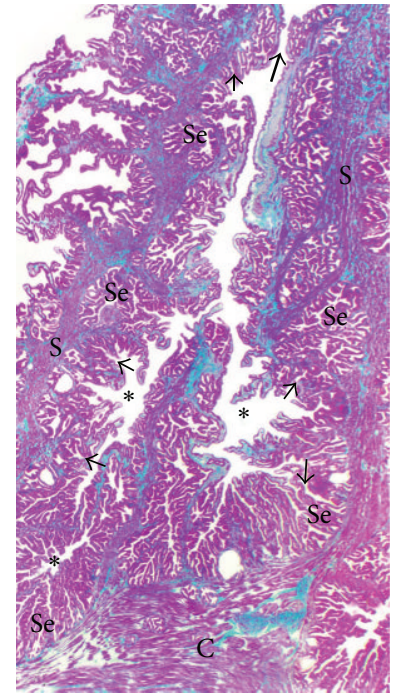

FIGURE 14: Photomicrograph of the prostate during spring showing the secretory end pieces (Se) drained directly by tertiary ducts (thin arrow) into collecting sinuses (asterisk), which are drained into long primary duct (thick arrow). Fibromuscular capsule (C), septa (S), and collagen fibers (green colour). Crossmon's trichrome stain. $\times 25$.

ratio reached its maximal value (about $0.270 \pm 0.009$ ). The connective tissue was abundant and the interstitial connective tissue/glandular tissue ratio reached the maximal value (about $0.480 \pm 0.018$ ).

Seasonal variations were also observed in the prostate of bucks [15], rams [25], camels [26], and rats [64]. In addition, reducing androgen production by the Leydig cells causes involution of the prostatic epithelium and growth of stroma in adult animals $[65,66]$.

The duct system of the prostate of the donkey was organized into tertiary, secondary (central collecting sinuses), and primary ducts. The latter opened into dorsal aspect of the prostatic urethra. Contradictive speculations were mentioned concerning the duct system organization in prostate of the different animals. In stallions and bulls, the prostate has intercellular canaliculi in addition to the excretory ducts, which have the same glandular lining [39]. In camels, the prostate duct system was organized into connecting ducts, collecting sinuses, and interlobular ducts. The latter was lined with stratified epithelium, which changed near its termination into the transitional one [26]. In the present study, similar interlobular ducts were not absolutely seen where the interlobular connective tissue was free of them. In buffalo bulls, it was organized into intra- and interlobular ducts [12]. However, Wrobel and Dellmann [19] in the prostate of domestic animals mentioned only intraglandular ducts where their lining epithelium changed from simple columnar to transitional one at their terminal portions.

Our results showed that $15-20$ prostatic duct openings are arranged on both sides of the Colliculus seminalis, representing the prostate gland ducts. Similar results were observed in equines [9], camels [46], buffalo bulls [12], and stallions [19]. Scanning electron microscope of the prostatic urethra showed that these openings appeared as elevated dome-shaped papillae upon the urethral surface (Figure 18).

The glandular epithelial cells of the prostate of the donkey reacted strongly to PAS, indicating the presence of neutral mucopolysaccharides. This reaction reached maximal intensity and amount during spring. During summer, the PAS reaction was nearly the same or somewhat slightly 


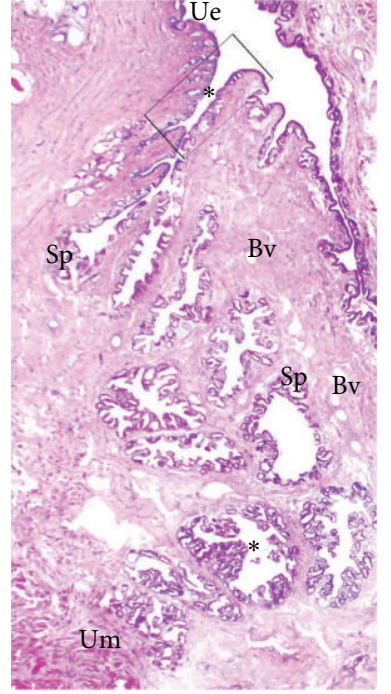

(a)

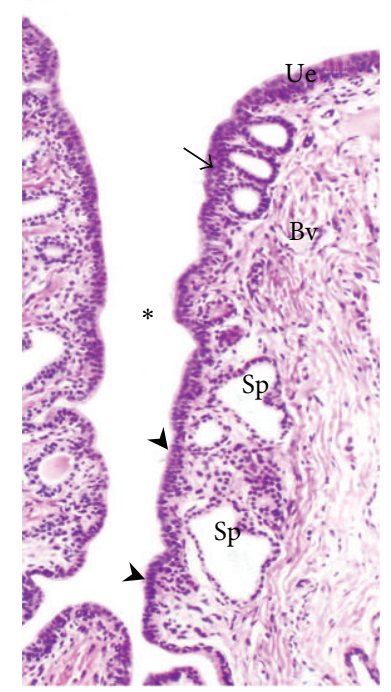

(b)

FIGURE 15: (a) Photomicrographs showing the penetration of the primary ducts (asterisk) to the urethral muscle (Um) during spring and high magnification of the marked area and (b) the change of the lining epithelium from bilayered epithelium (arrowhead) to stratified cuboidal (arrow) as that of the urethral epithelium (Ue). Secretory portions accompanied the duct (Sp), blood vessels (Bv). Haematoxylin and eosin stain. (a) $\times 25$. (b) $: \times 200$.

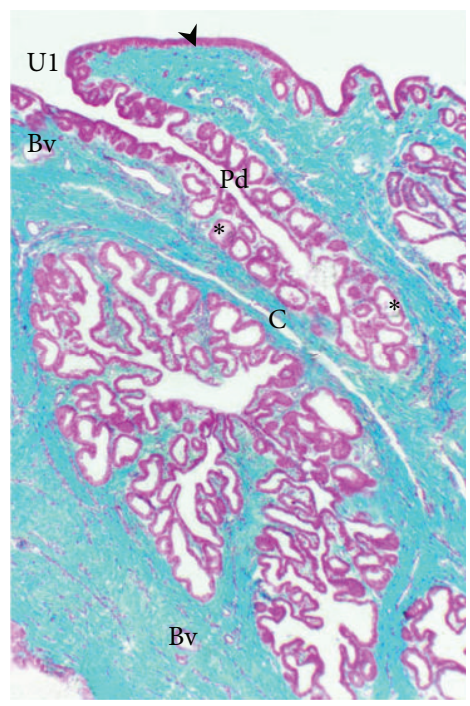

(a)

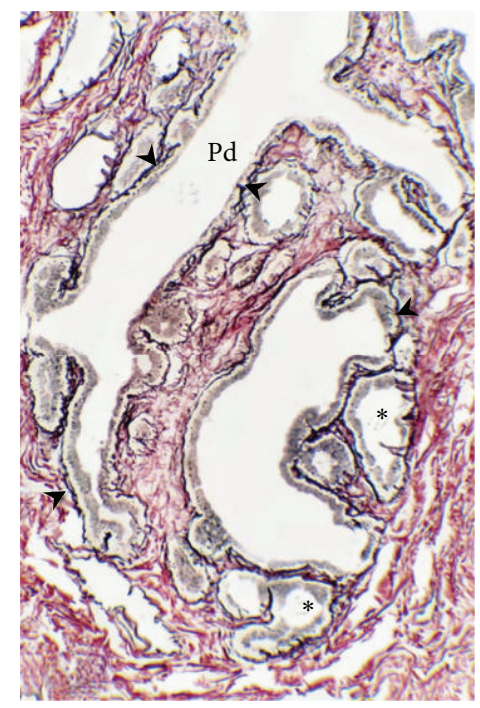

(b)

FIgURE 16: (a) Photomicrographs showing the presence of collagenous fibers (green colour) in the connective tissue layer supporting the primary duct (Pd) during autumn. Secretory end pieces accompanied the duct (asterisk). Urethral epithelium (arrowhead), urethral lumen $(\mathrm{Ul})$, cavernous spaces $(\mathrm{C})$, and blood vessels $(\mathrm{Bv})$. Crossmon's trichrome stain. $\times 50$. (b) Photomicrograph of the reticular fibers network (arrowhead) supporting the accompanied secretory end pieces (asterisk). Collagenous fibers (brown colour). Gomori’s stain. $\times 200$.

decreased more than that during spring. Then it reached its lowest reactivity during winter. In the epithelial cells of the prostate of rabbits, the neutral mucopolysaccharides were the precursors of fructose in the prostatic secretion [67].

Seasonal variations with PAS were also recorded in the secretory end pieces of the prostate of red deer and rams. In red deer, strong PAS-positive granules were observed in the epithelial lining of the prostatic tubules during the rut than in the pre-rut season [14]. In rams, during winter the PAS-positive granules were observed in the majority of the active cells, and these granules increased in amount during spring and summer and reached their maximum during autumn [25]. In camels, the total glandular reactivity to PAS is greater in spring and winter than in autumn and summer. 


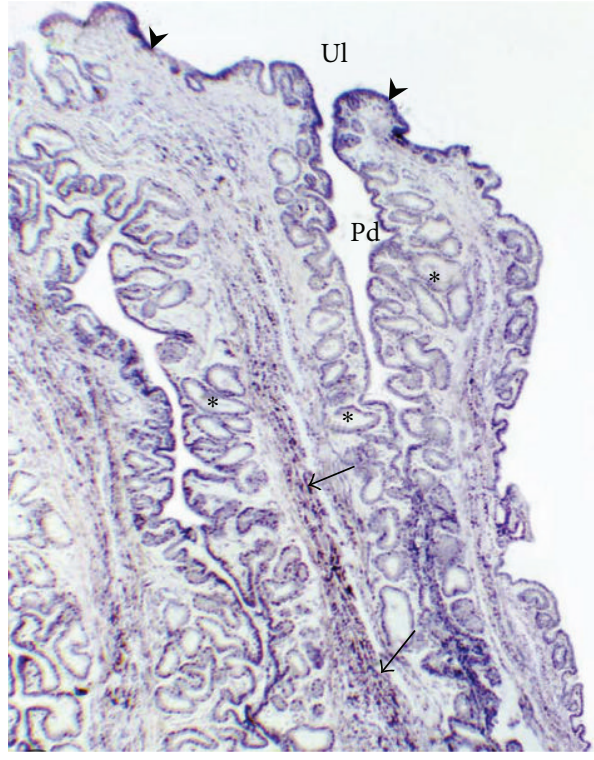

(a)

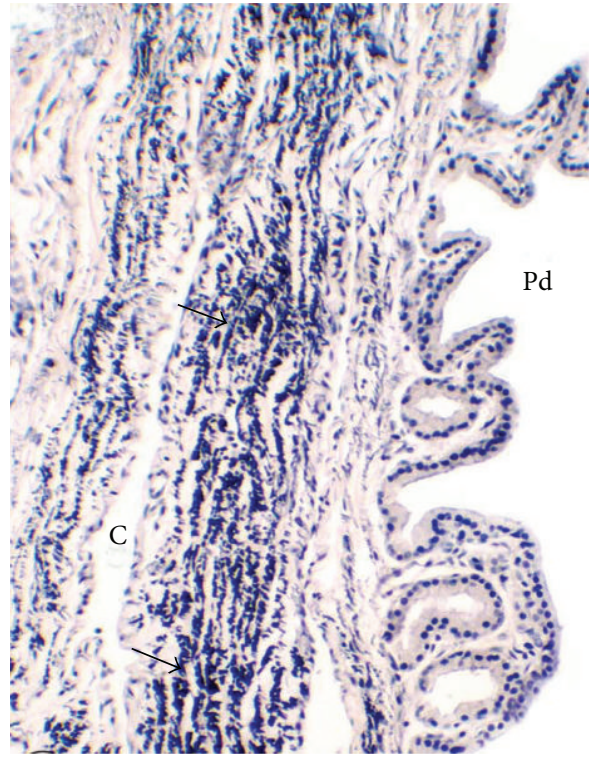

(b)

FIGURE 17: (a) Photomicrographs showing the parallelly arranged elastic fibers (thin arrow) to the longitudinal axis of the primary duct (Pd) during autumn. Secretory portions (asterisk) accompanying the duct, and urethral epithelium (arrowhead). Verhoff's stain. $\times 25$. (b) High magnification photomicrograph of the elastic fibers (thin arrow) in the wall of the primary duct (Pd) during autumn. Cavernous spaces (C). Verhoff's stain. $\times 200$.

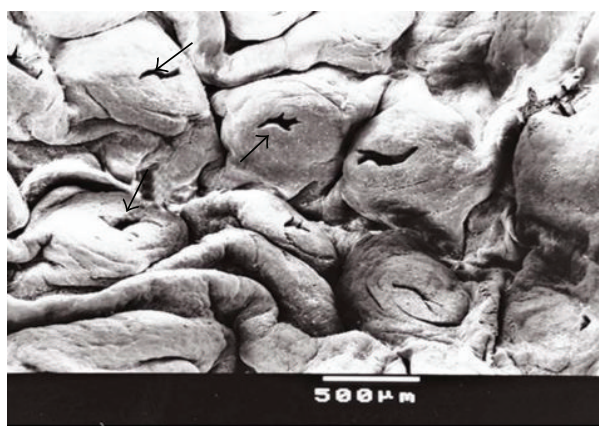

(a)

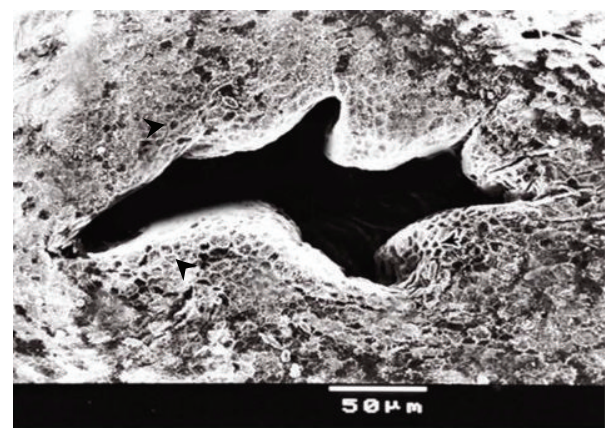

(c)

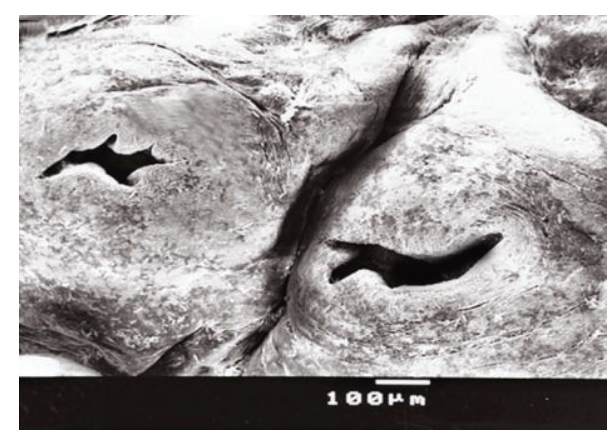

(b)

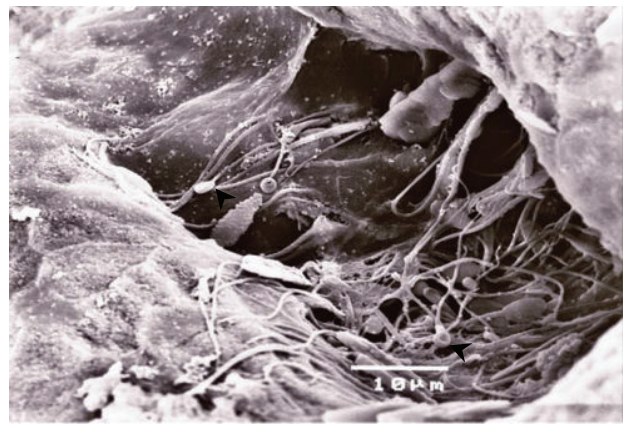

(d)

FIGURE 18: (a) Scanning electron micrograph of the luminal surface of the prostatic urethra at the level of the Colliculus seminalis during spring showing the arrangement of the prostate gland openings (arrow) into somewhat parallel rows. ((b)-(c)) High magnification scanning electron micrographs of (a) showing the elevated dome-shaped like papillae of the duct openings with its irregular oval appearance and hexagonal-shaped cell surface (arrowhead). (d) High magnification scanning electron micrograph of the prostate duct opening containing variable numbers of spermatozoa (arrowhead). Scale bar was demonstrated on each figure. 


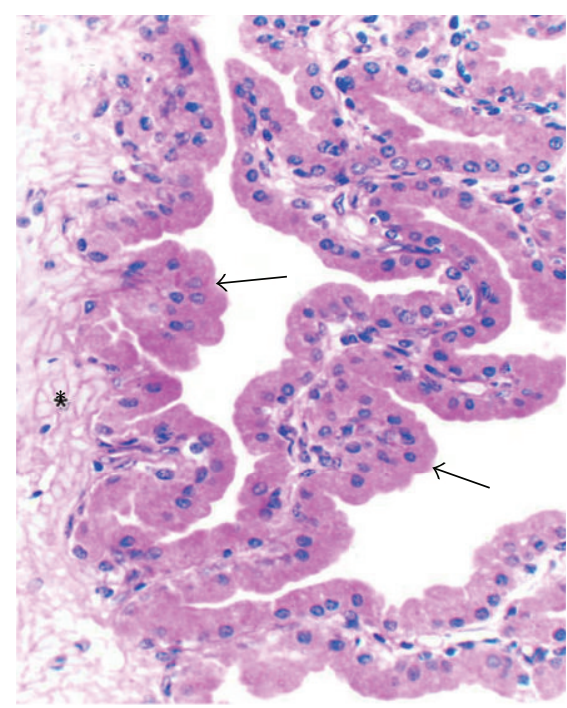

(a)

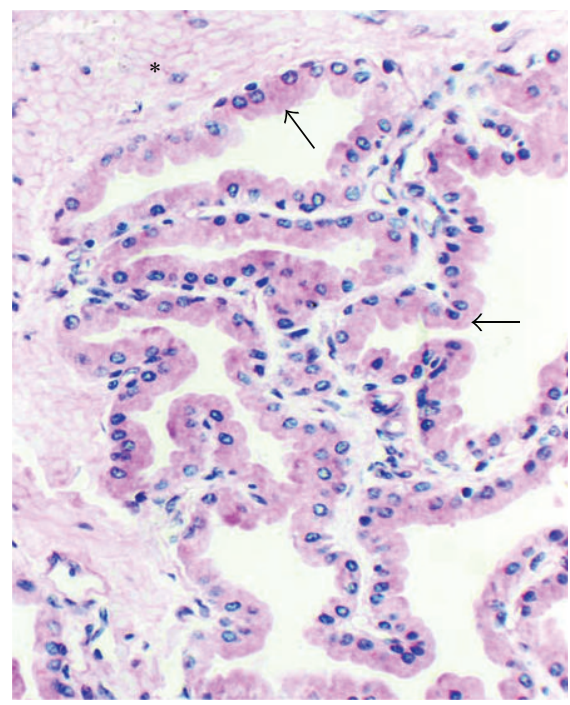

(c)

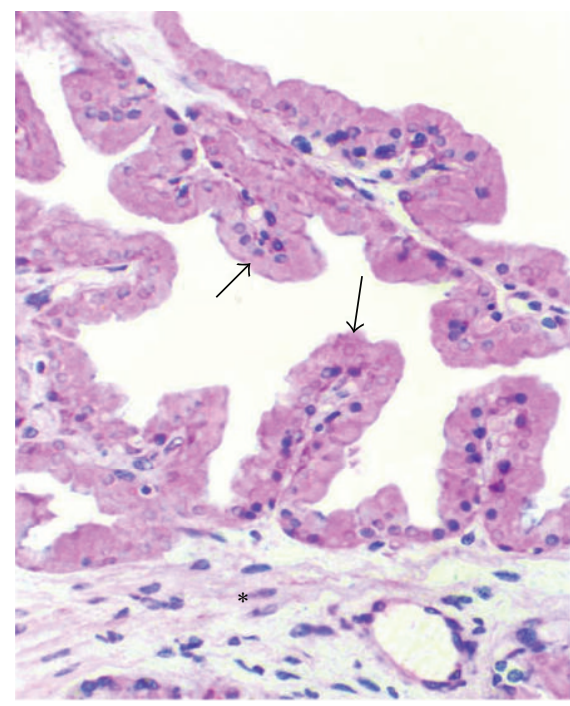

(b)

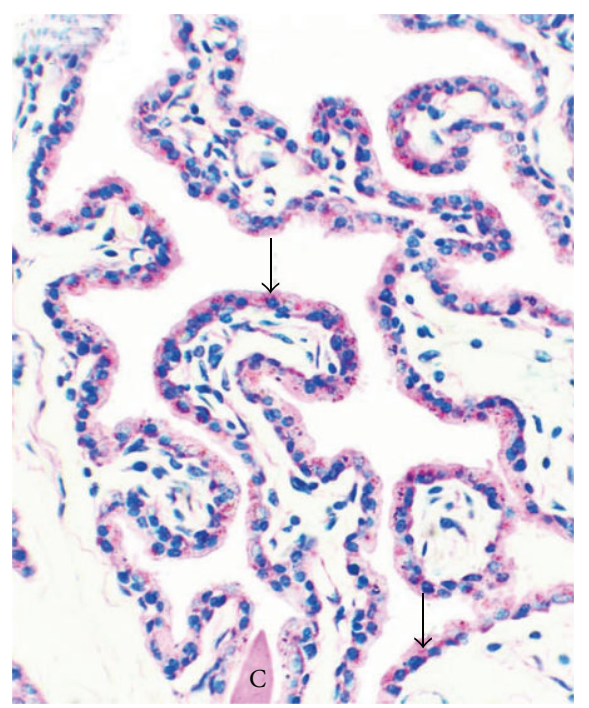

(d)

FIGURE 19: Photomicrographs showing the PAS reactivity within glandular epithelium (arrow) of the prostate gland of the donkey. Strong PAS positive reaction was observed during spring (a). This reaction decrease in intensity during summer (b) and becomes moderate during autumn (c). During winter (d), the majority of the secretory end pieces are weakly reacted, except the lipofuscin granules. Weakly reacted smooth muscle fiber bundles and connective tissue stroma (asterisk). Concretes (C). PAS/haematoxylin stain. $\times 400$.

This simply reflects the change in the amount of neutral mucopolysaccharides secreted by the prostate along the year being maximal in spring and minimal in summer [26].

In this work, the PAS-positive cells did not reveal any significant positive reaction to Best's carmine. Similar results were observed in dogs [5], buffalo bulls [48], and ferrets [68], where glycogen could not be observed in the prostate of these animals. These results were contrary to those observed in one-day-old poppy, opossum, shrew, camels, and young calves $([5,11,23,45,56]$, resp.), where fine glycogenic granules were demonstrated in the prostatic glandular epithelium. These glycogen granules might be involved in the metabolic activity of the secretory units of camel's prostate [11].

Similar to that observed in the prostate of boars [6], dogs and cats [69], camels [24, 26], and Viscacha [70], the prostate of the donkey was devoid of any alcianophilic positive reaction. This result was in contrary that observed in the prostate of dogs [71], goats [16], buffalo bulls [12, 17, 48], and ferrets [68] in which the prostatic epithelium contained alcianophilic positive granules.

From the previous results, the secretory materials of the prostate gland of the donkey were neutral mucopolysaccharides and the prostate was suggested to be serous gland while in bulls $[8,72]$ and buffalo bulls $[12,17]$ two types of prostatic epithelial cells were recorded: serous and mucous cell types.

In a common agreement with Arcadi [5] Seaman and Winell [22] Brandes and Bourne [73], Miraglia et al. [18], Ali et al. [24], Nasr and Moustafa [11], Sudhakar et al. [45] in the prostate gland of dogs, men, common marmoset, camels, and buffalo bulls, respectively, the prostate of the donkey reacted 


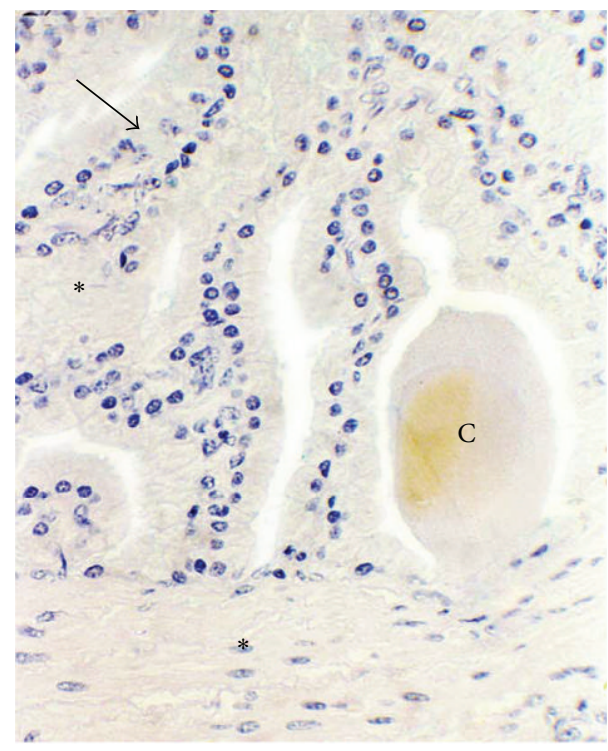

(a)

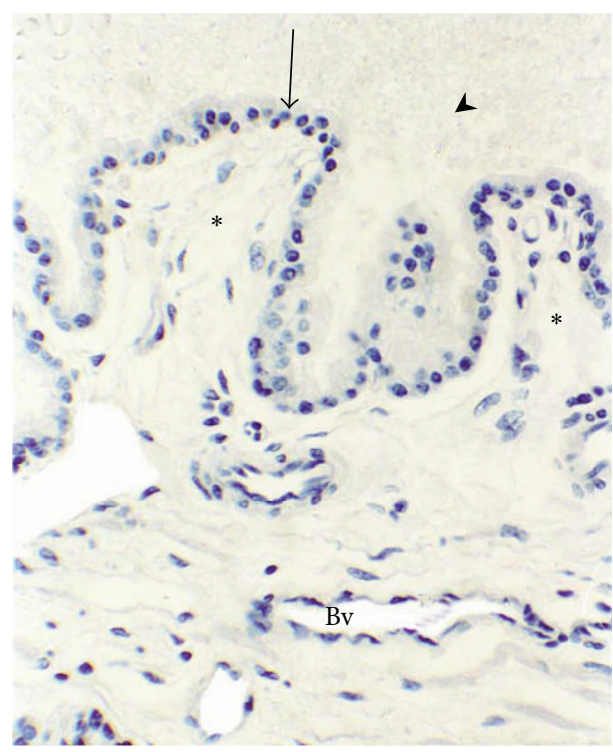

(b)

Figure 20: Photomicrographs of the prostate after alcian blue staining during spring (a) and winter (b) showing the negative reactivity of the glandular epithelium (arrow), stroma (asterisk), luminal contents (arrowhead), concretes (C), and blood vessels (Bv). Alcian blue/haematoxylin stain. $\times 400$.

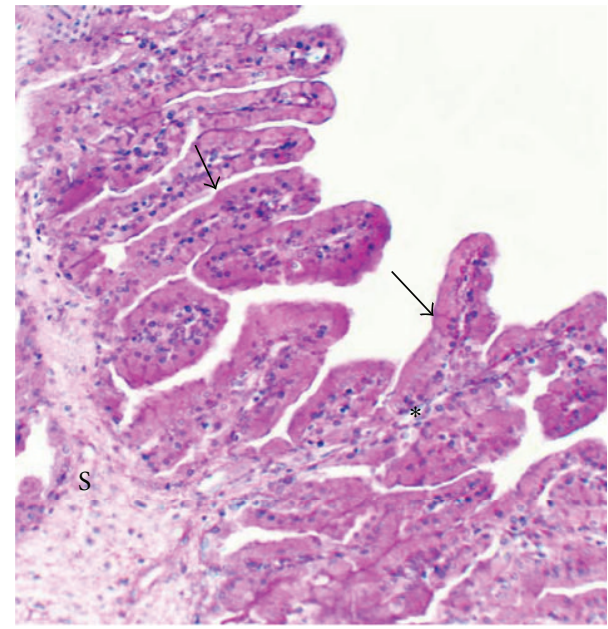

(a)

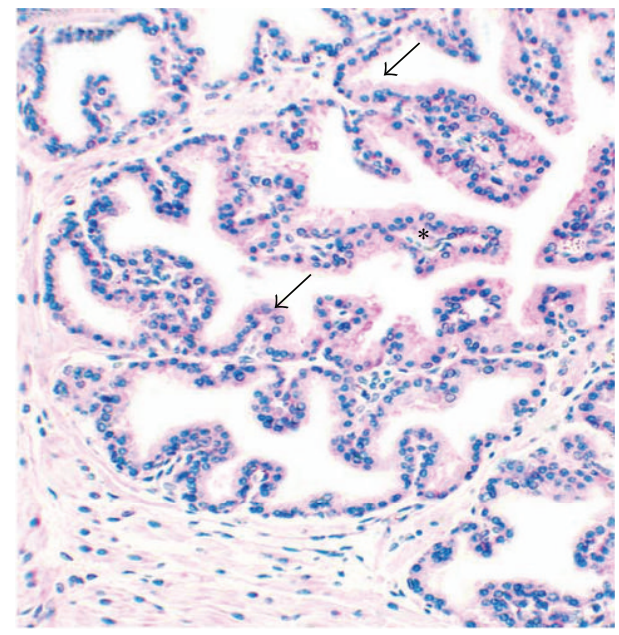

(b)

FIGURE 21: Photomicrographs of the prostate gland during spring (a) and winter (b) after alcian blue/PAS/haematoxylin staining showing nearly the same picture as PAS reactivity. Glandular epithelium (arrow), interstitial connective tissue (asterisk), and septa (S). $\times 200$.

positively to Sudan black stain. Few sudanophilic granules were distributed in the cytoplasm of the glandular and ductal epithelial cells during spring. During the other seasons, the intensity and amount of sudanophilic granules was increased.

Seasonal variations in the amount of lipid content were observed in the glandular epithelial cells of the prostate of bucks, in which the maximal sudanophilic materials were demonstrated in autumn (active season), while materials collected at the end of spring showed minimal lipid contents [15]. This was on contrary to that observed in the prostate of goats [16] and buffalo bulls [48], which were free from sudanophilic materials.
The secretory materials of the prostate of domestic animals increased spermatozoal motility and contributed to vaginal plug formation. In bulls, the secretory fluids contain high quantities of fructose and citric acid; however, little else is known regarding its function [1]. In stallions, the prostatic secretion forms about $25-30 \%$ of the total volume of the ejaculate, and its function is to neutralize the seminal plasma, made acid by accumulation of metabolic carbon dioxide and lactate, and to initiate active movements of the ejaculated spermatozoa [19]. Also, Dym [74] reported that the prostatic secretion of men was colourless fluid that contained zinc, citric acid, and numerous proteolytic enzymes. 


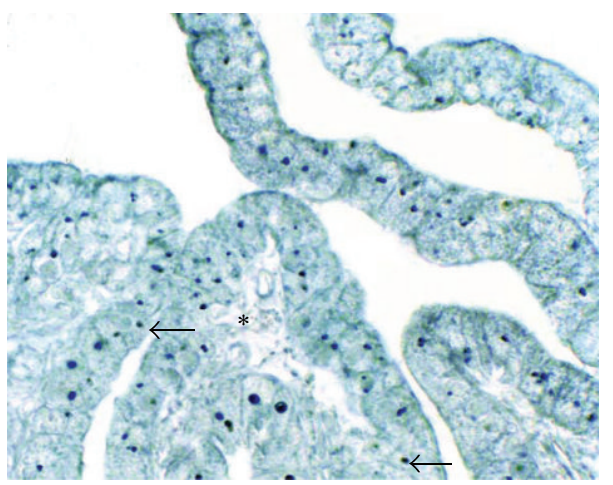

(a)

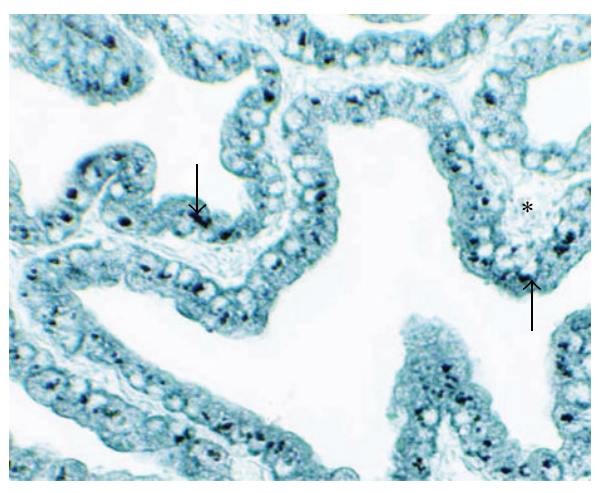

(b)

FIGURE 22: Photomicrographs showing few sudanophilic granules within the glandular and ductal epithelial cells (arrow) of the prostate of the donkey during spring (b). These granules increase in intensity and amount during winter (b). Negatively reacted interstitial connective tissue (asterisk). Sudan black stain. $\times 400$.

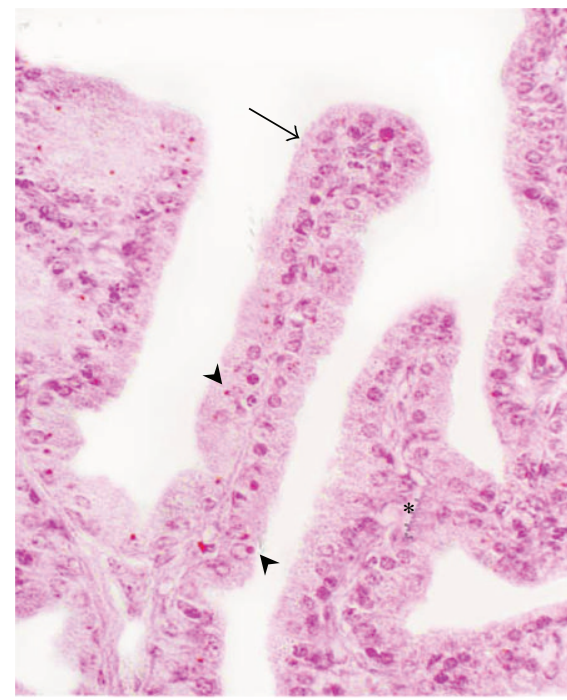

(a)

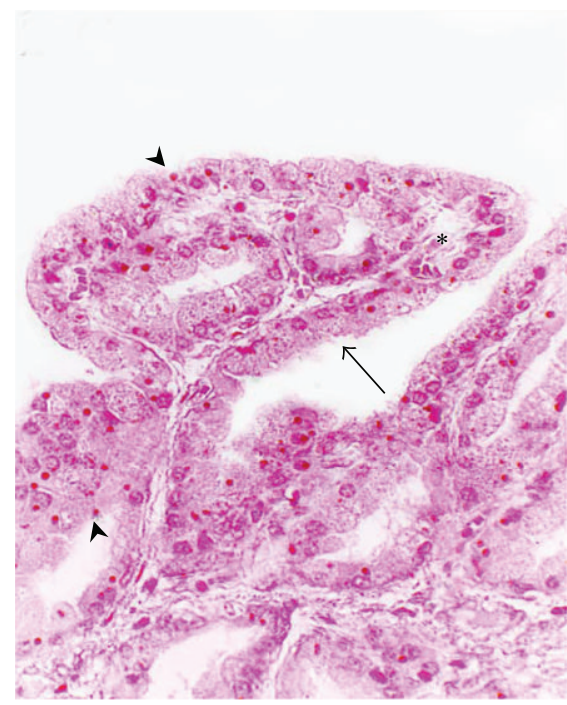

(c)

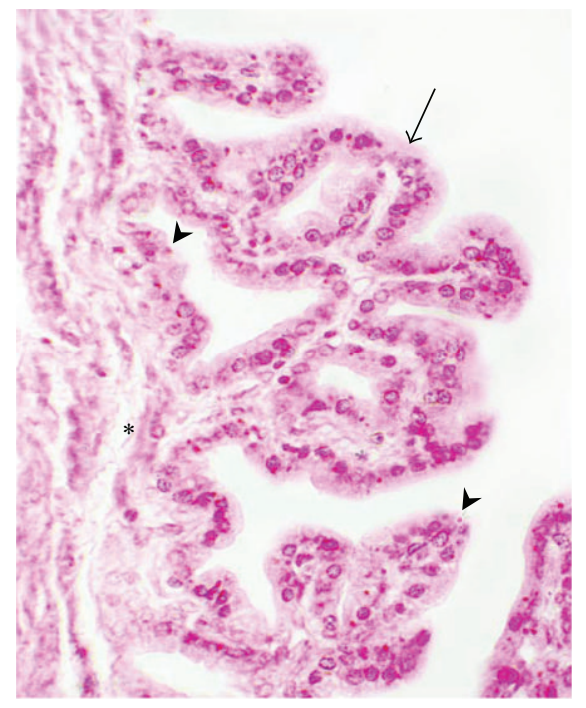

(b)

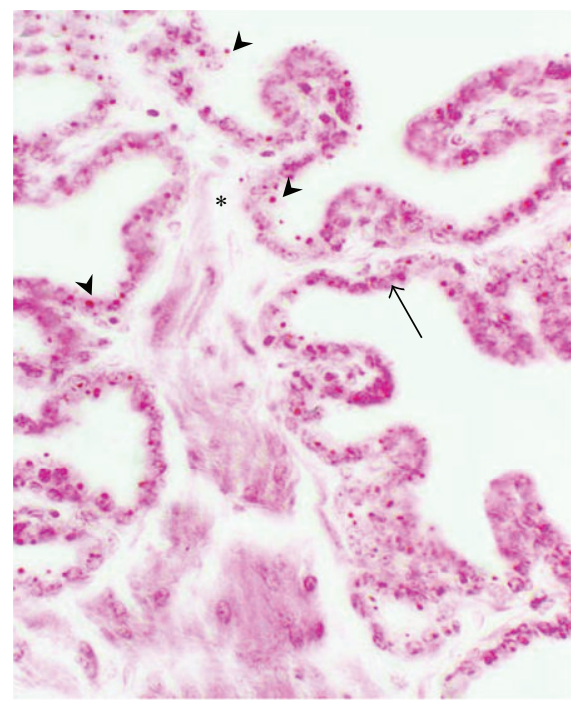

(d)

FIGURE 23: Photomicrographs showing the variation in the amount of lipofuscin granules (arrowhead) within the glandular epithelial cells (arrow) of the prostate of the donkey. Few granules are observed during spring (a), which increase in amount during summer (b) with further increase during autumn $(c)$, where they reach their maximal amount during winter (d). Smooth muscle fibers (S), interstitial connective tissue (asterisk). Long Ziehl-Neelsen technique $\times 400$. 
The most potent one was fibrinolysin, which played a role in liquefaction of semen.

In conclusion, the prostate gland of donkey appeared more active during spring, which is manifested by increase in the epithelial height, decrease in the interstitial connective tissue glandular tissue ratio, and strong PAS reactivity in the epithelial lining of the secretory end pieces. This reactivity decreased during other seasons of the year. Minimal reactivity was recorded during winter.

\section{Acknowledgments}

The authors would like to express deep thanks for Assiut University for funding of the project. Grateful thanks were extended for lab technicians in the Department of Anatomy and Histology, Assiut University for their grateful help.

\section{References}

[1] W. J. Banks, Male Reproductive System, Mosby Year Book, St. Louis, Lo, USA, 3rd edition, 1993.

[2] M. C. G. Davies Morel, Equine Reproductive Physiology, Breeding and Stud Management, CABI Publishing, 2nd edition, 2003.

[3] A. S. Abou-Elhamd, A. O. Salem, and A. A. Selim, "Histological and histochemical studies on the ampulla of the deferent duct of donkey (Equus asinus)," Journal of Advanced Veterinary Research, vol. 2, no. 4, pp. 261-270, 2012.

[4] H. A. Bern, "The effects of sex steroids on the sex accessories of the male Dutch rabbit," American Journal of Anatomy, vol. 84, no. 2, pp. 231-277, 1949.

[5] J. A. Arcadi, "Some polysaccharide components of the prostate gland of the dog," The Anatomical Record, vol. 112, no. 3, pp. 593607, 1952.

[6] R. N. Aitken, "A histochemical study of the accessory genital glands of the boar," Journal of Anatomy, vol. 94, pp. 130-142, 1960.

[7] R. V. Short, T. Mann, and M. F. Hay, "Male reproductive organs of the African elephant, Loxodonta africana," Journal of Reproduction and Fertility, vol. 13, no. 3, pp. 517-536, 1967.

[8] R. A. Kainer, L. C. Faulkner, and M. Abdel-Raouf, "Glands associated with the urethra of the bull," American Journal of Veterinary Research, vol. 30, no. 6, pp. 963-974, 1969.

[9] S. Sisson, The Anatomy of the Domestic Animals, vol. 1, W. B. Saunders, Philadelphia, Pa, USA, 1975.

[10] D. H. Cormack, “The male reproductive system," in Ham's Histology, J. B. Lippincott, Philadelphia, Pa, USA, 9th edition, 1987.

[11] M. T. Nasr and I. A. Moustafa, "Morphohistological and histochemical studies on the prostate gland of the camel (Camelus dromedarius) during different ages," Journal of the Egyptian Veterinary Medical Association, vol. 48, pp. 317-334, 1988.

[12] Chandrapal and M. B. L. Bharadwaj, "Microanatomy of corpus prostate in buffalo (Bulbalus bulbalis) at different stages of maturity," Indian Veterinary Journal, vol. 70, pp. 1025-1029, 1993.

[13] R. N. Aitken, "Observations on the development of the seminal vesicles, prostate and bulbourethral glands in the ram," Journal of Anatomy, vol. 93, no. 1, pp. 43-51, 1959.

[14] E. Aughey, "Histology and histochemistry of the male accessory glands of the red deer, Cervus elaphus L," Journal of Reproduction and Fertility, vol. 18, no. 3, pp. 399-407, 1969.
[15] A. Selim A, Histological and histochemical studies on the accessory genital glands of balady buck with special references to seasonal changes [M.S. thesis], Assiut University, Assiut, Egypt, 1974.

[16] K. H. Wrobel, "Histochemical examinations of the prostatic parenchyma in the goat," Zentralblatt für Veterinärmedizin C, vol. 1, pp. 64-72, 1972.

[17] A. Abou-Elmagd and K. H. Wrobel, "The periurethral glandular complex in the water buffalo: an ultrastructural, histological and lectin-histochemical study," Archives of Histology and Cytology, vol. 52, no. 5, pp. 501-512, 1989.

[18] T. Miraglia, M. Telles Filho, and A. L. Branco, "The male reproductive system of the common marmoset (Callithrix jacchus)," Acta Anatomica, vol. 76, no. 4, pp. 594-611, 1970.

[19] K. H. Wrobel and H. D. Dellmann, "Male reproductive system," in Textbook of Veterinary Histology, H.-D. P. Dellmann, Ed., Lea \& Febiger, Philadelphia, Pa, USA, 4th edition, 1993.

[20] A. E. Aly and A. A. Khabir, "The ultrastructure of normal prostatic acini of the camel (Camelus dromedarius)," Zagazig Veterinary Journal, vol. 13, pp. 79-89, 1986.

[21] M. B. Amin and D. G. Bostwick, "Pigment in prostatic epithelium and adenocarcinoma: a potential source of diagnostic confusion with seminal vesicular epithelium," Modern Pathology, vol. 9, no. 7, pp. 791-795, 1996.

[22] A. R. Seaman and M. Winell, "The ultrafine structure of the normal prostate gland of the dog," Acta Anatomica, vol. 51, pp. $1-28,1962$.

[23] U. Kanwar and C. Sheikher, "Morphological and cytochemical studies on the shrew prostate gland," Acta Anatomica, vol. 98, no. 2, pp. 194-198, 1977.

[24] H. A. Ali, K. A. Moniem, and M. D. Tingari, "Some histochemical studies on the prostate, urethral and bulbourethral glands of the one humped camel (Camelus dromedarius)," Histochemical Journal, vol. 8, no. 6, pp. 565-578, 1976.

[25] A. A. Abbas, Histological and histochemical studies of the accessory genital glands of the balady ram with special reference to age and seasonal variations [M.S. thesis], Faculty of Veterinary Medicine, Zagazig University, 1976.

[26] E.-S. M. Mosallam, Histological and histochemical studies of the male accessory glands of the adult camel (Camelus dromedarius) in the different seasons of the year [Ph.D. thesis], Cairo, Egypt, 1981.

[27] H. F. Harris, "On the rapid conversion of haematoxylin into haematin in staining reactions," Journal of Applied Microscopy and Laboratory Methods, vol. 3, p. 777, 1900.

[28] J. D. Bancroft and A. Steven, Theory and Practice of Histological Techniques, Churchill Livingstone, New York, NY, USA, 4th edition, 1996.

[29] G. Crossmon, "A modification of Mallory's connective tissue with a discussion of principles involved," The Anatomical Record, vol. 69, pp. 33-38, 1937.

[30] P. Böck, Romeis Mikroskopishe Technik, vol. 17, Urban und Schwarzenberg, München, Germany, 1989.

[31] F. H. Verhoeff, "Some new staining methods of wide applicability. Including a rapid differential stain for elastic tissue," The Journal of the American Medical Association, vol. 50, p. 876, 1908.

[32] J. D. Bancroft and A. Steven, Theory and Practice of Histological Techniques, Churchill Livingstone, New York, NY, USA, 4th edition, 1996.

[33] G. Gomori, "Silver impregnation of reticulum in paraffin sections," The American Journal of Pathology, vol. 13, no. 6, pp. 993-1002, 1937. 
[34] J. F. A. McManus, "Histological demonstration of mucin after periodic acid," Nature, vol. 158, no. 4006, p. 202, 1946.

[35] H. F. Steedman, "Alcian blue 8GS; a new stain for mucin," The Quarterly Journal of Microscopical Science, vol. 91, pp. 477-479, 1950.

[36] R. W. Mowry, "Observations on the use of sulphuric ether for the sulphation of hydroxyl groups in tissue sections," Journal of Histochemistry \& Cytochemistry, vol. 4, p. 407, 1956.

[37] F. Best, "Über karmin Färbung des Glykogens und der Kerne," Zeitsch. Wissenschaft. Microsk. \& Mikrosk. Technick, vol. 23, pp. 319-322, 1906.

[38] O. B. Bayliss and C. W. M. Adams, "Bromine-Sudan Black: a general stain for lipids including free cholesterol," The Histochemical Journal, vol. 4, no. 6, pp. 505-515, 1972.

[39] A. Trautmann and J. Fiebiger, "The male genital organs," in Fundamentals of the Histology of Domestic Animals, R. E. Habel and E. L. Biberstein, Eds., Comstock Publishing Associates Itheca, New York, NY, USA, 1957, translated and revised from 8th and 9th German.

[40] R. Nickel, A. Schummer, and E. Seiferle, "Male genital organs," in The Viscera of the Domestic Mammals, Paul Parey, Berlin, Germany, 1st edition, 1973, translated and revised by Sack W. O.

[41] K. M. Dyce, W. O. Sack, and C. J. G. Wensing, "The urogenital apparatus," in Textbook of Veterinary Anatomy, W. B. Saunders, Philadelphia, Pa, USA, 2nd edition, 1996.

[42] M. F. A. Fahmy and A. M. H. Osman, "Certain morphological investigations on the male genital organs of water buffalo as guide for andrological diagnosis. IV. Accessory glands," Egyptian Journal of Veterinary Science, vol. 9, pp. 56-65, 1972.

[43] G. Fehér and A. Haraszti, "Beiträge zur Morphologie und $\mathrm{zu}$ den altersbedingten Veranderungen der akzessorischen Geschlechtsdrüsen von Stieren," Acta Veterinaria Hungarica, vol. 14, pp. 141-145, 1964.

[44] L. S. Sudhakar, L. D. Dhingra, and D. N. Sharma, "Histomorphological studies on the pars disseminata of the prostate gland of Murrah buffalo during postnatal development," Indian Journal of Animal Sciences, vol. 55, pp. 847-853, 1985.

[45] L. S. Sudhakar, L. D. Dhingra, and D. N. Sharma, "Histochemical studies on the prostate gland of Murrah Buffalo during postnatal development," Indian Veterinary Journal, vol. 62, pp. 221-226, 1985.

[46] H. A. Ali, M. D. Tingari, and K. A. Moniem, "On the morphology of the accessory male glands and histochemistry of the ampulla ductus deferentis of the camel (Camelus dromedarius)," Journal of Anatomy, vol. 125, no. 2, pp. 277-292, 1978.

[47] A. B. A. Badawy, R. S. A. Ragab, and H. I. Youssef, "Histological and biochemical observations on the accessory reproductive glands of castrated camels," Journal of the Egyptian Veterinary Medical Association, vol. 42, pp. 113-120, 1982.

[48] M. H. G. Moussa, A. B. A. Badawy, M. H. A. Kandil, and Y. M. Shahin, "Histological and histochemical studies of the accessory genital glands of buffalo-bull (Bubalis bubalis)," Anatomischer Anzeiger, vol. 153, no. 5, pp. 429-439, 1983.

[49] S. S. Rochel, A. Bruni-Cardoso, S. R. Taboga, P. S. L. Vilamaior, and R. M. Góes, "Lobe identity in the Mongolian gerbil prostatic complex: a new rodent model for prostate study," Anatomical Record, vol. 290, no. 10, pp. 1233-1247, 2007.

[50] D. H. Cormack, "The male reproductive system," in Essential Histology, Lippincott-Ravanen, Philadelphia, Pa, USA, 1st edition, 1997.
[51] T. S. Yao and O. N. Eaton, "Postnatal growth and histological development of reproductive organs in male goats," The American Journal of Anatomy, vol. 95, no. 3, pp. 401-431, 1954.

[52] A. Tsukise and K. Yamada, "Histochemistry of glycoconjugates in the secretory epithelium of the goat bulbourethral gland," Acta Anatomica, vol. 129, no. 4, pp. 344-352, 1987.

[53] S. C. Jacobs, B. A. Beehler, and G. Boese, "The prostate of the gorilla," Prostate, vol. 5, no. 6, pp. 597-603, 1984.

[54] A. Abou-Elmagd, "Morphologische Untersuchungen an Wandepithel und Anhangsdrüsen der Urethra des mannlichen Wasserbüffels (Bubalis bubalis)," in Inaugural-Dissertation zur Erlangung der Tiermedizinischen Doktorwürde der Tierärztlichen, Fakultät der Ludwig-Maximilians-Universität, München, Germany, 1988.

[55] J. A. Chandler, B. G. Timms, M. S. Morton, and G. V. Groom, "Proceedings: effect of cadmium administration in vivo on plasma testosterone and the ultrastructure of accessory sex organs of the rat," Journal of Endocrinology, vol. 69, no. 3, p. 21, 1976.

[56] Z. Hruban, J. Martan, A. Slesers, D. F. Steiner, M. Lubran, and M. Rechcigl Jr., "Fine structure of the prostatic epithelium of the opossum (Didelphis virginiana Kerr)," Journal of Experimental Zoology, vol. 160, no. 1, pp. 81-105, 1965.

[57] C. Hohbach and H. Ueberberg, "Ultrastructural and histochemical aspects of prostatic secretion in the dog," Pathology Research and Practice, vol. 173, no. 3, pp. 225-235, 1982.

[58] H. E. S. Marei, H. A. El-Habback, and K. F. Abou-Esa, "Histology, fine structure and carbohydrate histochmistry of the epithelium of the accessory male genital glands of the Egyptian balady goat," Veterinary Medical Journal Giza, vol. 52, pp. 165182, 2004.

[59] J. Muntzing, H. Myhrberg, and J. Saroff, "Histochemical and ultrastructural study of prostatic tissue from baboons treated with antiprostatic drugs," Investigative Urology, vol. 14, no. 2, pp. 162-167, 1976.

[60] J. B. Brennick, J. X. O’Connell, G. R. Dickersin, and R. H. Young, "Lipofuscin pigmentation (so-called "melanosis") of the prostate," American Journal of Surgical Pathology, vol. 18, no. 5, pp. 446-454, 1994.

[61] Y.-J. Niu, T.-X. Ma, J. Zhang, Y. Xu, R.-F. Han, and G. Sun, "Androgen and prostatic stroma," Asian Journal of Andrology, vol. 5, no. 1, pp. 19-26, 2003.

[62] M. Jara, R. Carballada, and P. Esponda, "Age-induced apoptosis in the male genital tract of the mouse," Reproduction, vol. 127, no. 3, pp. 359-366, 2004.

[63] J. Muntzing and T. Nilsson, "Lipofuscin in malignant and non-malignant human prostatic tissue," Zeitschrift für Krebsforschung und klinische Onkologie, vol. 77, no. 2, pp. 166-170, 1972.

[64] M. Garcia-Florez, C. A. Oliveira, and H. F. Carvalho, "Early effects of estrogen on the rat ventral prostate," Brazilian Journal of Medical and Biological Research, vol. 38, no. 4, pp. 487-497, 2005.

[65] S. A. Thompson, D. R. Rowley, and P. M. Heidger Jr., "Effects of estrogen upon the fine structure of epithelium and stroma in the rat ventral prostate gland," Investigative Urology, vol. 17, no. 1, pp. 83-89, 1979.

[66] Z. Weihua, M. Warner, and J.-Å. Gustafsson, "Estrogen receptor beta in the prostate," Molecular and Cellular Endocrinology, vol. 193, no. 1-2, pp. 1-5, 2002. 
[67] V. E. Filotto and P. Mongiardini, "Ricerche istochimiche sulle ghiandole annesse allápparato genitale maschile di (Lepus cuniculus)," Folia Clinica et Biologica, vol. 30, pp. 239-250, 1961.

[68] S. Jacob and S. Poddar, "Morphology and histochemistry of the ferret prostate," Acta Anatomica, vol. 125, no. 4, pp. 268-273, 1986.

[69] M. Wrobel, "Histochemical and electron microscopical examinations of the prostate gland in dog and cat," Zentralblatt für Veterinärmedizin C, vol. 1, pp. 93-116, 1972.

[70] E. M. Chaves, C. Aguilera-Merlo, V. Filippa, F. Mohamed, S. Dominguez, and L. Scardapane, "Anatomical, histological and immunohistochemical study of the reproductive system accessory glands in male viscacha (Lagostomus maximus maximus)," Journal of Veterinary Medicine Series C, vol. 40, no. 1, pp. 11-20, 2011.

[71] A. R. Seaman, "Cytological observation on the prostate gland of the dog," The Anatomical Record, vol. 118, p. 353, 1954.

[72] J. Schencker, "Zur funktionellen Anatomie der Prostata des Rindes," Acta Anatomica, vol. 9, pp. 69-102, 1965.

[73] D. Brandes and G. H. Bourne, "Histochemistry of the human prostate: normal and neoplastic," The Journal of Pathology and Bacteriology, vol. 71, no. 1, pp. 33-36, 1956.

[74] M. Dym, “The male reproductive system," in Histology, Cell and Tissue Biology, L. Weiss, Ed., Macmillan Press, 5th edition, 1983. 

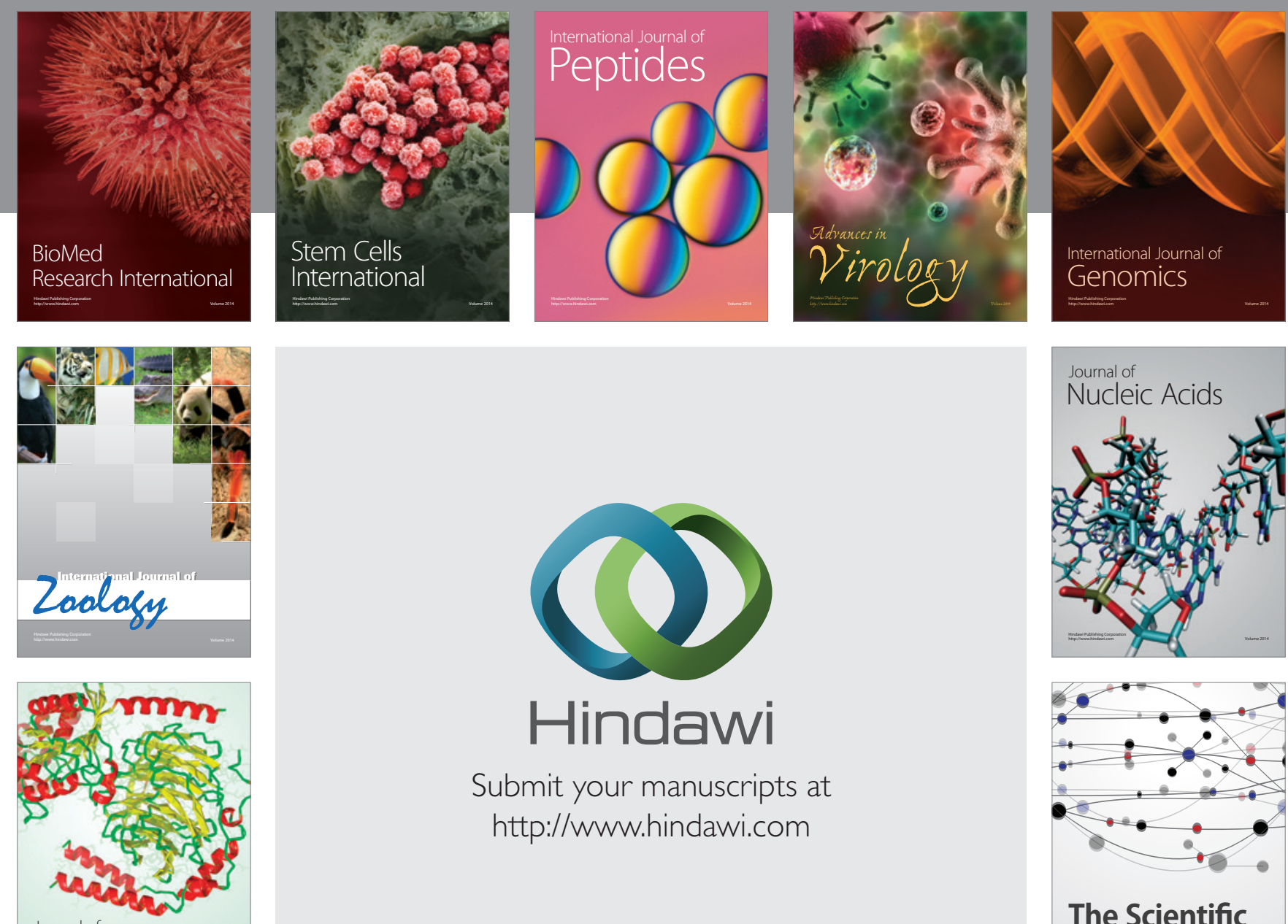

Submit your manuscripts at

http://www.hindawi.com

Journal of
Signal Transduction
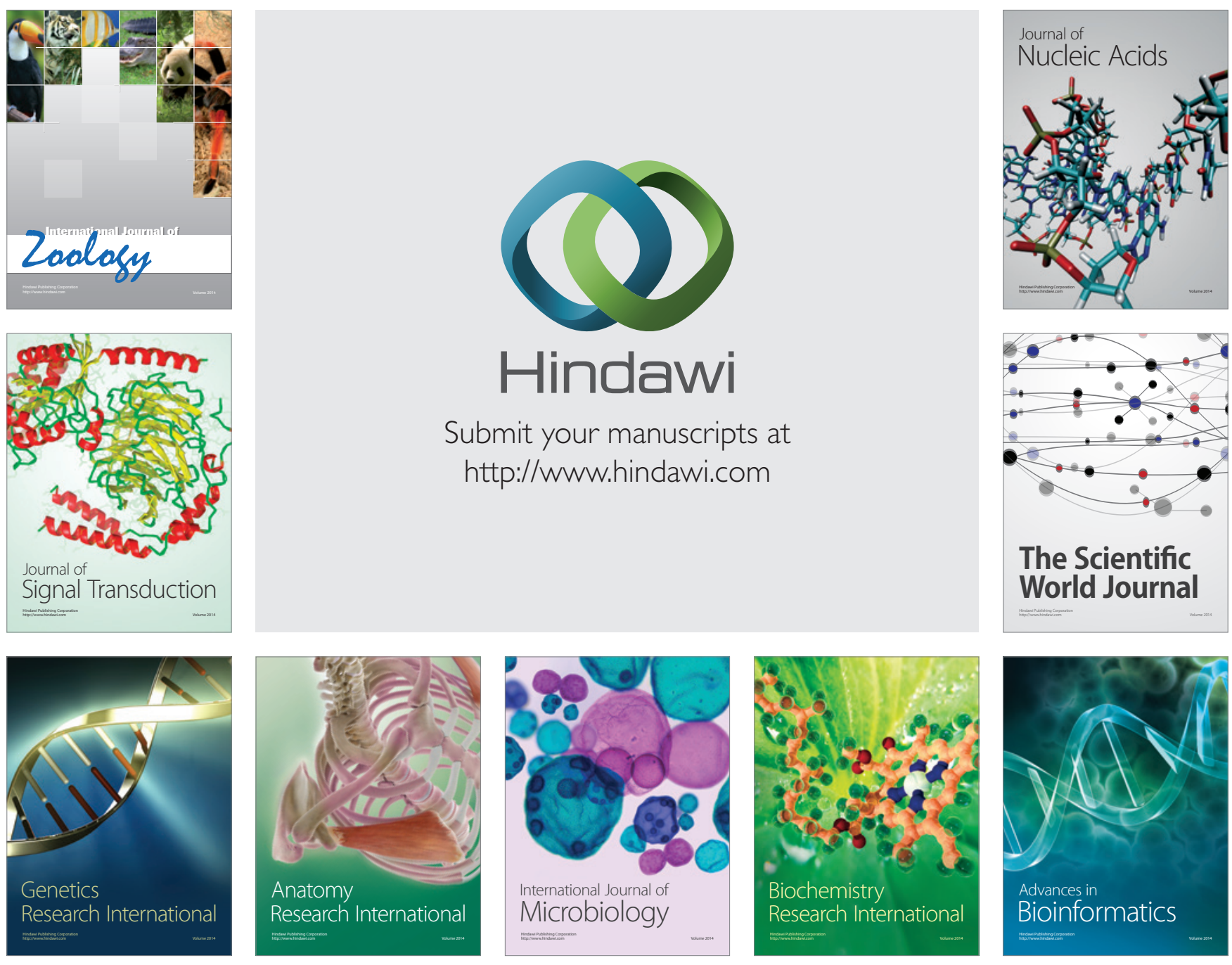

The Scientific World Journal
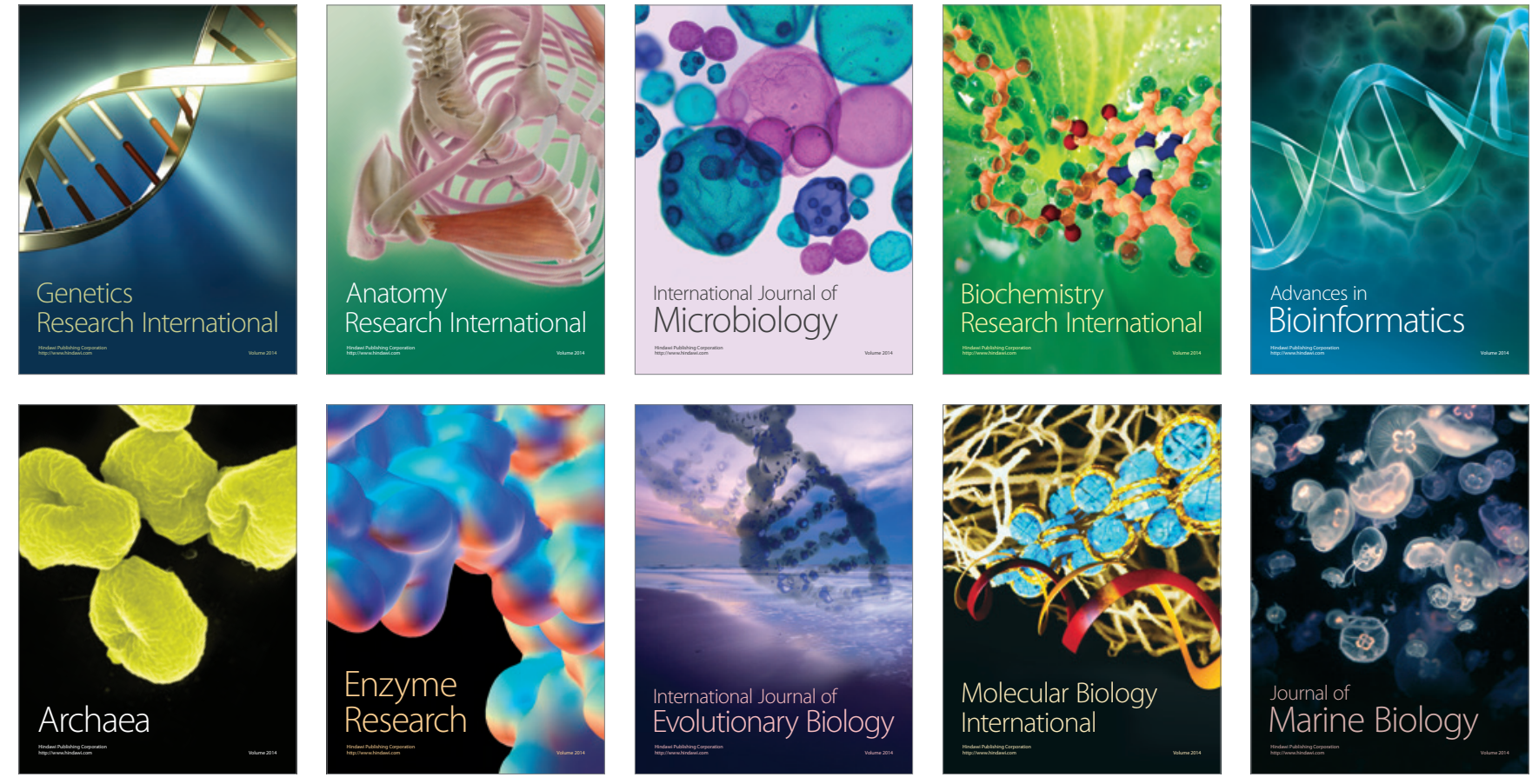